Prepared in cooperation with the San Bernardino Valley Municipal Water District

\title{
Geologic Structure of the Yucaipa Area Inferred from Gravity Data, San Bernardino and Riverside Counties, California
}

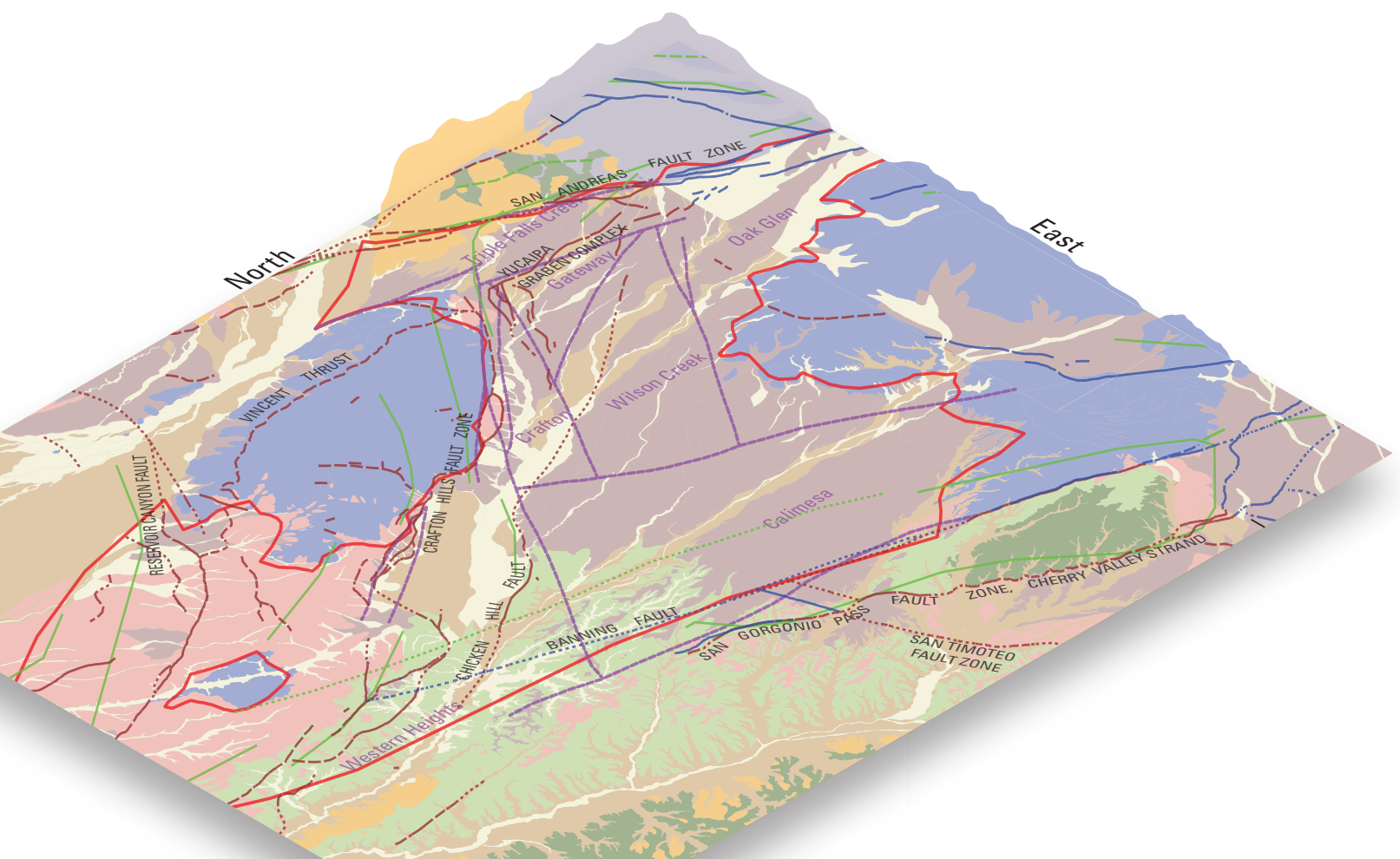

Open-File Report 2016-1127 
Cover. Geology of the Yucaipa area, California. See figure 2 for more information. 


\section{Geologic Structure of the Yucaipa Area Inferred from Gravity Data, San Bernardino and Riverside Counties, California}

By Gregory 0. Mendez, V. E. Langenheim, Andrew Morita, and Wesley R. Danskin

Prepared in cooperation with the San Bernardino Valley Municipal Water District

Open-File Report 2016-1127 


\title{
U.S. Department of the Interior SALLY JEWELL, Secretary
}

\section{U.S. Geological Survey Suzette M. Kimball, Director}

\author{
U.S. Geological Survey, Reston, Virginia: 2016
}

For more information on the USGS - the Federal source for science about the Earth, its natural and living resources, natural hazards, and the environment-visit http://www.usgs.gov or call 1-888-ASK-USGS.

For an overview of USGS information products, including maps, imagery, and publications, visit http://www.usgs.gov/pubprod/.

Any use of trade, firm, or product names is for descriptive purposes only and does not imply endorsement by the U.S. Government.

Although this information product, for the most part, is in the public domain, it also may contain copyrighted materials as noted in the text. Permission to reproduce copyrighted items must be secured from the copyright owner.

Suggested citation:

Mendez, G.O., Langenheim, V.E., Morita, Andrew, and Danskin, W.R., 2016, Geologic structure of the Yucaipa area inferred from gravity data, San Bernardino and Riverside Counties, California: U.S. Geological Survey Open-File Report 2016-1127, 22 p., http://dx.doi.org/10.3133/ofr20161127.

ISSN 2331-1258 (online) 


\section{Contents}

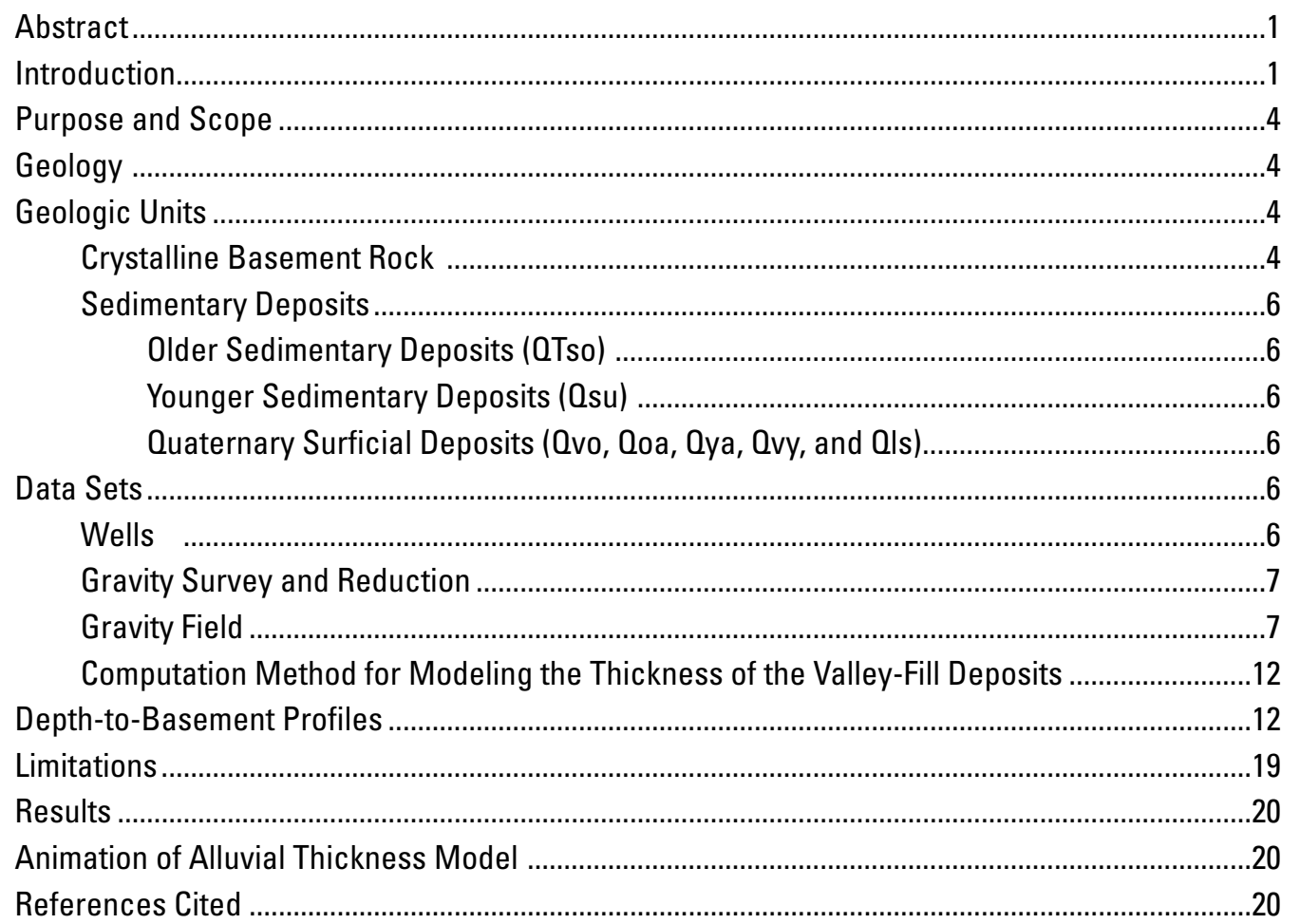




\section{Figures}

1. Map showing the location of the Yucaipa area, California ...................................................

2. Map showing the geology of the Yucaipa area, California...................................................

3. Map showing selected wells, profile lines, and subbasin boundaries in the Yucaipa area, California...

4. Photographs showing basement rock at map site 10 and 28 on table 1 in the Yucaipa area, California...

5. Map showing isostatic residual gravity field in the Yucaipa area, California ..................11

6. Map showing estimated thickness of the valley-fill deposits in the Yucaipa area, California

7A. Schematics showing five profiles in the Yucaipa area, southern California.

Profile line A-A'

7B. Schematics showing five profiles in the Yucaipa area, southern California.

Profile line B-B'

7C. Schematics showing five profiles in the Yucaipa area, southern California.

Profile line $\mathrm{C}-\mathrm{C}^{\prime}$

7D. Schematics showing five profiles in the Yucaipa area, southern California.

Profile line D-D'

7E. Schematics showing five profiles in the Yucaipa area, southern California. Profile line $\mathrm{E}-\mathrm{E}^{\prime}$

8. Video animation showing land surface, geology, faults, wells, and basement rocks in the Yucaipa area, California.

\section{Tables}

1. State well number, station identification, local name, location, bore-hole depth, and depth-to-basement rocks for selected wells in the Yucaipa area, California ............8

2. Assumed density contrast with depth in the Yucaipa area, California 


\section{Conversion Factors}

U.S. customary units to International System of Units

\begin{tabular}{|c|c|c|}
\hline Multiply & $\mathrm{By}$ & To obtain \\
\hline \multicolumn{3}{|c|}{ Length } \\
\hline inch (in.) & 25.4 & millimeter (mm) \\
\hline foot $(\mathrm{ft})$ & 0.3048 & meter $(\mathrm{m})$ \\
\hline mile (mi) & 1.609 & kilometer (km) \\
\hline \multicolumn{3}{|c|}{ Area } \\
\hline square foot $\left(\mathrm{ft}^{2}\right)$ & 0.09290 & square meter $\left(\mathrm{m}^{2}\right)$ \\
\hline \multicolumn{3}{|c|}{ Volume } \\
\hline gallon (gal) & 3.785 & liter (L) \\
\hline cubic inch $\left(\right.$ in $\left.^{3}\right)$ & 16.39 & cubic centimeter $\left(\mathrm{cm}^{3}\right)$ \\
\hline \multicolumn{3}{|c|}{ Flow rate } \\
\hline cubic foot per second $\left(\mathrm{ft}^{3} / \mathrm{s}\right)$ & 0.02832 & cubic meter per second $\left(\mathrm{m}^{3} / \mathrm{s}\right)$ \\
\hline \multicolumn{3}{|c|}{ Mass } \\
\hline ounce, avoirdupois (oz) & 28.35 & $\operatorname{gram}(\mathrm{g})$ \\
\hline pound, avoirdupois (lb) & 0.4536 & kilogram $(\mathrm{kg})$ \\
\hline \multicolumn{3}{|c|}{ Hydraulic conductivity } \\
\hline foot per day (ft/d) & 0.3048 & meter per day (m/d) \\
\hline
\end{tabular}

Temperature in degrees Celsius $\left({ }^{\circ} \mathrm{C}\right)$ may be converted to degrees Fahrenheit $\left({ }^{\circ} \mathrm{F}\right)$ as follows:

${ }^{\circ} \mathrm{F}=\left(1.8 \times{ }^{\circ} \mathrm{C}\right)+32$.

Temperature in degrees Fahrenheit $\left({ }^{\circ} \mathrm{F}\right)$ may be converted to degrees Celsius $\left({ }^{\circ} \mathrm{C}\right)$ as follows:

${ }^{\circ} \mathrm{C}=\left({ }^{\circ} \mathrm{F}-32\right) / 1.8$.

\section{Datum}

Vertical coordinate information is referenced to the North American Vertical Datum of 1988 (NAVD 88).

Horizontal coordinate information is referenced to the North American Datum of 1983 (NAD 83).

Elevation, as used in this report, refers to distance above the vertical datum. 


\section{Abbreviations}

$\begin{array}{ll}\text { GPS } & \text { Global Positioning System } \\ \text { mGal } & \text { milli-Galileo } \\ \text { Qls } & \text { landslide deposits } \\ \text { Qoa } & \text { old alluvium } \\ \text { Qsu } & \text { younger sedimentary deposits } \\ \text { QTso } & \text { older sedimentary deposits } \\ \text { Ovo } & \text { very old alluvium } \\ \text { Ovy } & \text { very young alluvium } \\ \text { Oya } & \text { young alluvium } \\ \text { RTK } & \text { Real Time Kinematic } \\ \text { USGS } & \text { U.S. Geological Survey }\end{array}$




\section{Well-Numbering System}

Wells are identified and numbered according to their location in the rectangular system for the subdivision of public lands. The identification consists of the township number, north or south; the range number, east or west; and the section number. Each section is further divided into sixteen 40 -acre tracts lettered consecutively (except I and 0 ), beginning with " $A$ " in the northeast corner of the section and progressing in a sinusoidal manner to " $R$ " in the southeast corner. Within the 40-acre tract, wells are sequentially numbered in the order they are inventoried. The final letter refers to the base line and meridian. In California, there are three base lines and meridians; Humboldt (H), Mount Diablo (M), and San Bernardino (S). All wells in the study area are referenced to the San Bernardino base line and meridian (S). Well numbers consist of 15 characters and follow the format 002S002W02M001S.

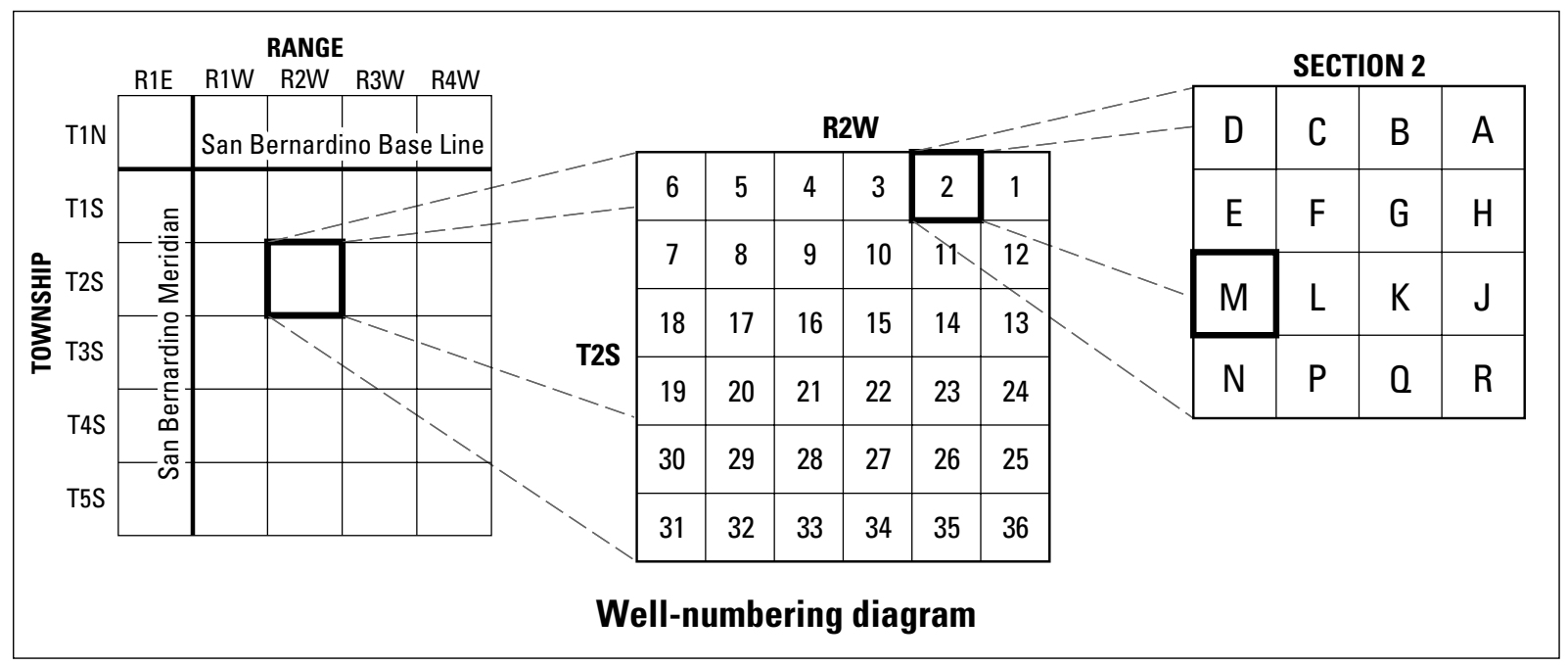


This page intentionally left blank. 


\title{
Geologic Structure of the Yucaipa Area Inferred from Gravity Data, San Bernardino and Riverside Counties, California
}

\author{
By Gregory 0. Mendez, V.E. Langenheim, Andrew Morita, and Wesley R. Danskin
}

\section{Abstract}

In the spring of 2009, the U.S. Geological Survey, in cooperation with the San Bernardino Valley Municipal Water District, began working on a gravity survey in the Yucaipa area to explore the three-dimensional shape of the sedimentary fill (alluvial deposits) and the surface of the underlying crystalline basement rocks. As water use has increased in pace with rapid urbanization, water managers have need for better information about the subsurface geometry and the boundaries of groundwater subbasins in the Yucaipa area. The large density contrast between alluvial deposits and the crystalline basement complex permits using modeling of gravity data to estimate the thickness of alluvial deposits. The bottom of the alluvial deposits is considered to be the top of crystalline basement rocks. The gravity data, integrated with geologic information from surface outcrops and 51 subsurface borings (15 of which penetrated basement rock), indicated a complex basin configuration where steep slopes coincide with mapped faults-such as the Crafton Hills Fault and the eastern section of the Banning Fault-and concealed ridges separate hydrologically defined subbasins.

Gravity measurements and well logs were the primary data sets used to define the thickness and structure of the groundwater basin. Gravity measurements were collected at 256 new locations along profiles that totaled approximately $104.6 \mathrm{~km}$ (65 mi) in length; these data supplemented previously collected gravity measurements. Gravity data were reduced to isostatic anomalies and separated into an anomaly field representing the valley fill. The 'valley-fill-deposits gravity anomaly' was converted to thickness by using an assumed, depth-varying density contrast between the alluvial deposits and the underlying bedrock.

To help visualize the basin geometry, an animation of the elevation of the top of the basement-rocks was prepared. The animation "flies over" the Yucaipa groundwater basin, viewing the land surface, geology, faults, and ridges and valleys of the shaded-relief elevation of the top of the basement complex.

\section{Introduction}

This report presents gravity data collected in 2009 by the U.S. Geological Survey (USGS), in cooperation with the San Bernardino Valley Municipal Water District, to investigate the subsurface structure and the depth to basement rocks beneath the Yucaipa area of southern California. The city of Yucaipa is about 12 miles (mi) southeast of the city of San Bernardino and $75 \mathrm{mi}$ east of the city of Los Angeles (fig. 1). Water-use increases due to rapid urbanization and reductions in supply due to drought have prompted water managers to have a need for better information about the subsurface geometry and boundaries of groundwater subbasins in the Yucaipa area. Previous groundwater investigations concluded that the Yucaipa subsurface is partitioned into seven subbasins (Moreland, 1970) based on known faults and barriers to groundwater flow; these operationally defined subbasins are in the Yucaipa groundwater subbasin of the Upper Santa Ana Valley groundwater basin delineated by the California Department of Water Resources (2004; fig. 2). This report is a first step in refining the picture of the Yucaipa groundwater basin and does not update or revise previously defined subbasin boundaries.

The study area (fig. 1) extends from the San Andreas Fault in the north to the San Timoteo Wash in the south and from the Crafton Hills in the west to the Yucaipa Hills in the east. Between the hills and mountains is a gently sloping area of unconsolidated deposits, commonly referred to as the Yucaipa plain. On the western side, the plain merges into the San Bernardino area, and on the southeast side, the plain opens to the San Gorgonio Pass. The Yucaipa plain ranges in elevation from about 1,800 to 3,600 feet (ft) above sea level and is surrounded by hills and mountains that range in elevation from about $3,000 \mathrm{ft}$ in the Crafton Hills, to $5,000 \mathrm{ft}$ along the ridge of the Yucaipa Hills, to more than 8,000 $\mathrm{ft}$ in the San Bernardino Mountains.

Lithologic logs and cores from multiple-well monitoring sites, combined with gravity data, improved the ability to evaluate the structure of the basement complex. The large density contrast between the alluvial deposits and the basement rocks permits using modeling of gravity data to estimate the thickness of alluvial deposits. Geologic information from surface outcrops and subsurface borings was used to constrain and calibrate the alluvial-thickness model. 


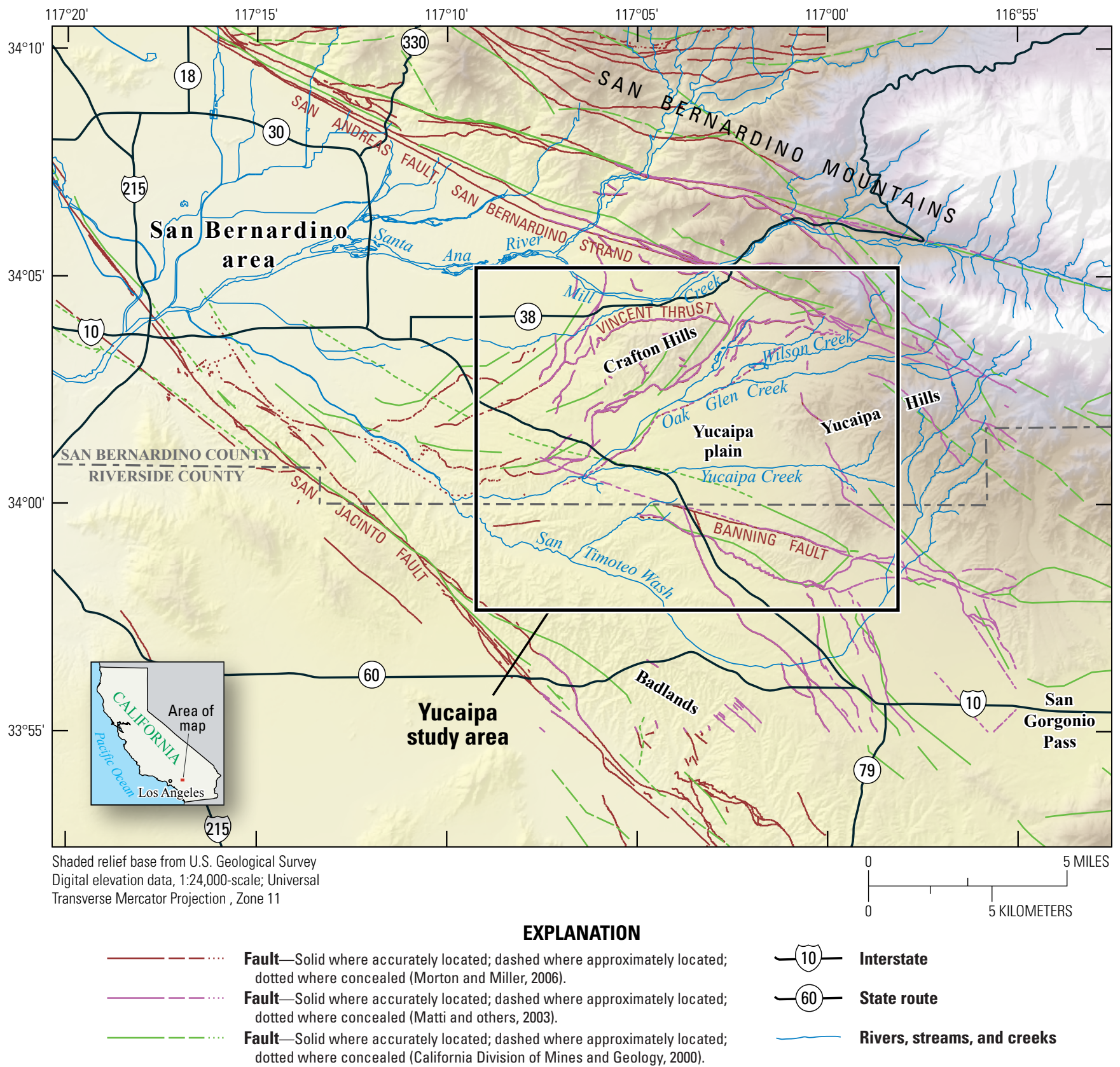

Figure 1. Location of the Yucaipa area, California. 


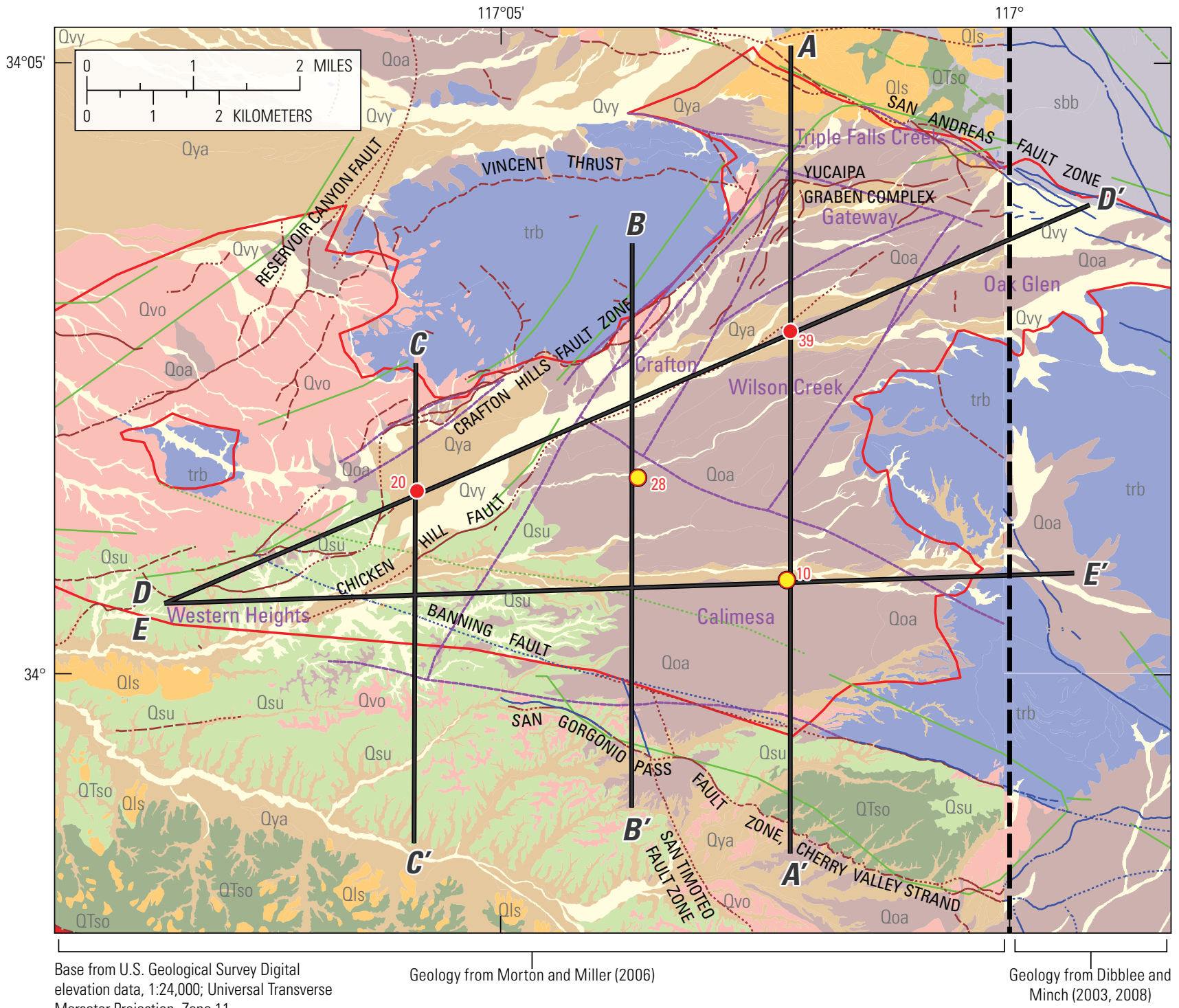

Mercator Projection, Zone 11

\section{EXPLANATION}

Geology_-Grouped by major geologic time (Dibblee and Minch, 2003, 2008 and Morton and Miller, 2006).

Surficial deposits

(Holocene to Pleistocene)

\begin{tabular}{|c|c}
\hline Ols & Landslide deposits \\
\cline { 1 - 1 } Ovy & Very young alluvium \\
\hline \hline Oya & Young alluvium \\
\hline \hline Ooa & Old alluvium \\
\hline \hline Ovo & Very old alluvium
\end{tabular}

Younger sedimentary deposits

$$
\text { (Pleistocene) }
$$

Qsu Younger sedimentary deposits

Older sedimentary deposits

(Pleistocene to Miocene)

QTSO Older sedimentary deposits (including San Timoteo and Mill Creek formation)
Crystalline basement rocks

(Pre-Tertiary)

\begin{tabular}{|c|c|}
\hline prb & Peninsular Ranges-type (in profiles) \\
\hline trb & San Gabriel Mountains-type \\
\hline (Triassic) & \\
\hline sbb & San Bernardino Mountains-type \\
\hline
\end{tabular}

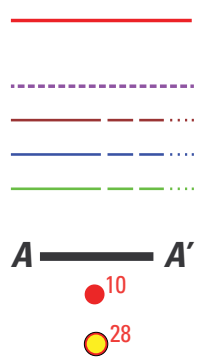

California Department of Water Resources (DWR) groundwater subbasin boundary—Upper Santa Ana Valley, Yucaipa subbasins, California Department of Water Resources, 2004; Bulletin 118-updated 2003.

Subbasin boundary —Faults and barriers (Moreland, 1970). Text in same color is subbasin name.

Fault—Solid where accurately located; dashed where approximately located; dotted where concealed (Morton and Miller, 2006).

Fault—Solid where accurately located; dashed where approximately located; dotted where concealed (Matti and others, 2003).

Fault-Solid where accurately located; dashed where approximately located; dotted where concealed (California Division of Mines and Geology, 2000).

10

Profile line-Letter designation is profile name, figure 7.

U.S. Geological Survey multiple-well monitoring site-Number refers to identification number in table 1.

U.S. Geological Survey multiple-well monitoring site that penetrates basement rocks-Number refers to identification number in table 1.

Figure 2. Geology of the Yucaipa area, California. 
Geologic Structure of the Yucaipa Area Inferred from Gravity Data, San Bernardino and Riverside Counties, California

\section{Purpose and Scope}

The purpose of this report is to identify the basin geometry with respect to the alluvial deposits and underlying basement rocks. The scope of the study included collecting gravity data at a scale that would allow evaluation of the ridges and valleys of the crystalline basement rocks. Gravity data from this report are to be used to help design a hydrogeologic framework model of the Yucaipa subbasins.

\section{Geology}

The Yucaipa area is underlain by unconsolidated and consolidated sedimentary materials and flanked on three sides by crystalline basement rocks that make up the local hills and mountains (figs. 1, 2). For at least the last million years or so, these upland areas have shed sediment into the lowland, gradually producing the sedimentary fill that transmits and stores groundwater beneath the Yucaipa area. This sedimentary volume is not homogeneous; it has internal irregularities caused by variations in layering and sediment properties, and it is traversed by known and suspected faults that break the fill and impede groundwater flow. These two factors-lithologic variation and faulting - partition the Yucaipa subsurface into multiple groundwater subbasins (Moreland, 1970). The presence of bedrock ridges in the subsurface, where sedimentary deposits are thin, has been suspected to contribute to restricting groundwater flow between subbasins as well, but information about the geometry of these features has been sparse.

The geologic structure and landforms of the Yucaipa area are a result of regional tectonism. To the north of the Yucaipa area, the San Andreas fault zone (fig. 1) is a major fault that accommodates most of the relative motion between two tectonic plates - the North American Plate on the northeast and the Pacific Plate on the southwest (Harden, 1998). The San Jacinto and Banning Faults (fig. 1) are major right-lateral faults similar to the San Andreas Fault. Extension, or pulling apart of the crust, has formed a sediment-filled graben between the Crafton Hills fault zone and the Chicken Hill Fault (fig. 2; Matti and others, 1992, 2003; Matti and Morton, 1993; Anderson and others, 2004). The deformation associated with these faults has created several additional northeast-striking normal faults, some of which are visible at the land surface; additional faults have been inferred beneath the plain from geophysical and groundwater data. The normal-fault structures contrast with the Cherry Valley Fault at the southeast margin of the Yucaipa area (fig. 3), a north-dipping thrust fault that is interpreted to be the westernmost extent of the San Gorgonio Pass fault zone (Matti and others, 1992, 2003; Matti and Morton, 1993). In addition, not all faults are recently active and affect all sediments. For example, the Banning Fault (figs. 1, 2) is an old right-lateral strand of the San Andreas fault system that probably has not been active in Quaternary time. The fault trace is largely concealed, but Burnham and Dutcher (1960) report calcareous spring deposits that they associate with the fault's trace. Fault data from three reports (California Division of Mines and Geology, 2000; Matti and others, 2003; and Morton and Miller, 2006) showed that the Yucaipa area is structurally dissected.

The variety of geologic faults in the Yucaipa area results in some groundwater barriers that define some subbasins boundaries. Several groundwater subbasins were delineated by Burnham and Dutcher (1960) on the basis of groundwater occurrence and its movement within and between these faults and barriers. Subsequent data required some modification of the subbasin boundaries by Moreland (1970).

\section{Geologic Units}

The generalized surficial geology of the study area (fig. 2) was defined by combining data from three previously published geologic maps. The geologic map from Morton and Miller (2006) covers most of the study area. Additional areas are covered by the maps of Dibblee and Minch $(2003,2008)$. Matti and others (2003) provided a more detailed description of the geology of the Yucaipa area. In this report, previously mapped geologic units were combined into eight units to simplify mapping of the exposed geology in the Yucaipa groundwater subbasin: landslide deposits $(\mathrm{Qls})$, very young alluvium (Qvy), young alluvium (Qya), old alluvium (Qoa), very old alluvium (Qvo), older (QTso) and younger (Qsu) sedimentary deposits, and basement complex rocks-San Gabriel Mountains type (trb). Surficial geologic data primarily were used to delineate the boundary between the basin-fill deposits and the basement complex.

\section{Crystalline Basement Rock}

Crystalline basement rocks beneath the Yucaipa plain and that form the hills and mountains surrounding Yucaipa on the north, east, and west sides were deformed by ductile and brittle-ductile processes. Crystalline basement rocks form a hard, low-permeability foundation on which sedimentary material was subsequently deposited. The basement rocks are divided into three structurally and lithologically distinct groups (Matti and others, 1992, 2003; Matti and Morton, 1993; Rewis and others, 2006): (1) rocks of the Peninsular Ranges-type south of the Banning Fault (prb), (2) rocks of the San Gabriel Mountains-type between the Banning and San Andreas Faults (trb), and (3) rocks of the San Bernardino Mountains-type north of the San Andreas Fault (sbb). Basement rock of the San Bernardino Mountains-type (sbb) is not discussed here, because it lies exclusively northeast of the San Andreas Fault and is outside the Yucaipa groundwater subbasins. Basement rock of the Peninsular Ranges-type (prb) does not crop out in the study area, but lies beneath the sedimentary deposits south of the Banning Fault and consists of Mesozoic plutonic rocks and older metasedimentary rocks. Generally, these rocks are very hard; slightly to moderately weathered, where exposed in the south of the study area; and not extensively fractured. 


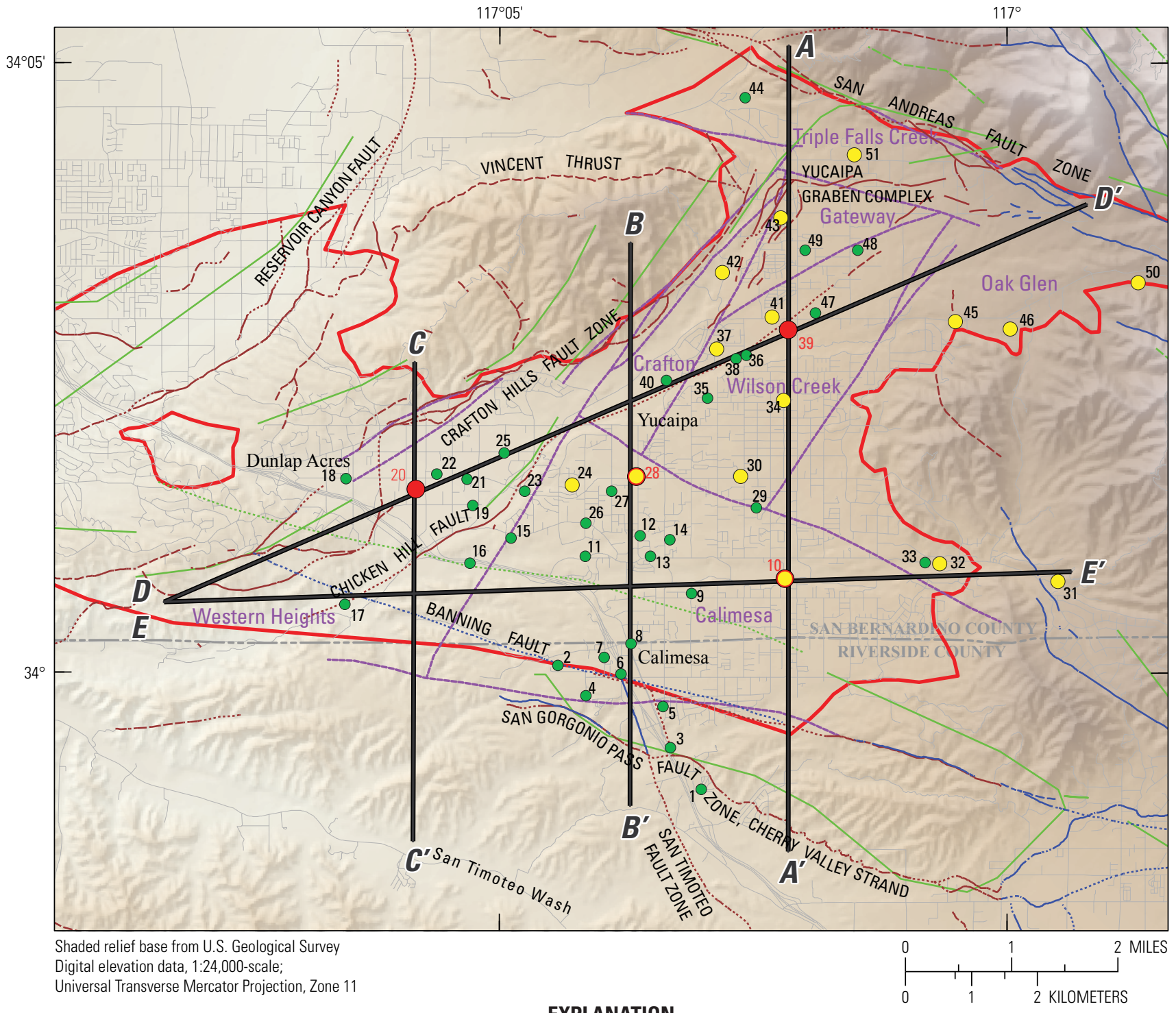

\section{EXPLANATION}

California Department of Water Resources (DWR) groundwater subbasin boundary—Upper Santa Ana Valley, Yucaipa subbasins, California Department of Water Resources, 2004; Bulletin 118-updated 2003.

Subbasin boundary-Faults and barriers (Moreland, 1970). Text in same color is subbasin name.

Fault-Solid where accurately located; dashed where approximately located; dotted where concealed (Morton and Miller, 2006).

Fault-Solid where accurately located; dashed where approximately located; dotted where concealed (Matti and others, 2003).

Fault-Solid where accurately located; dashed where approximately located; dotted where concealed (California Division of Mines and Geology, 2000).
$\boldsymbol{A}=\boldsymbol{A}^{\prime}$ Profile line-Letter designation is profile name, figure 7.
20 U.S. Geological Survey multiple-well monitoring site - Number refers to identification number in table 1.
$\mathrm{O}^{28} \quad$ U.S. Geological Survey multiple-well monitoring site that penetrates basement rocks-Number refers to identification number in table 1.
Production well that penetrates basement rocks.
2 Selected well site-Number refers to identification number in table 1.

Figure 3. Selected wells, profile lines, and subbasin boundaries in the Yucaipa area, California. 
Basement rock of San Gabriel Mountains-type (trb) crops out extensively in the hills surrounding the Yucaipa groundwater subbasins and in the subsurface is under the sedimentary fill. In the Yucaipa area, this geologic unit consists mainly of strongly foliated granitoid rocks, mainly of granodiorite to tonalite, that have been deformed by brittle-ductile and ductile shearing (Matti and others, 1992, 2003; Morton and Miller, 2006). Locally, the basement rock is intruded by Tertiary dikes and sills. In general, basement rocks of the San Gabriel Mountains-type, where exposed, are highly weathered and have abundant and closely spaced fractures.

\section{Sedimentary Deposits}

Sedimentary deposits of the Yucaipa basin consist of consolidated sedimentary rocks (typically older and deeper in the subsurface) and unconsolidated surficial sediments (typically younger and in shallower parts of the subsurface). Although these materials have diverse compositions and geotechnical characteristics, for the purposes of this report the mapped sedimentary deposits of Morton and others (2006) and Dibblee and Minch $(2003,2008)$ were grouped into three categories by major time period (fig. 2): (1) older sedimentary deposits (QTso), (2) younger sedimentary deposits (Qsu), and (3) Quaternary surficial deposits (Qvo, Qoa, Qya, Qvy, and Qls).

\section{Older Sedimentary Deposits (QTso)}

Deposits grouped in this unit consist of Miocene to midPleistocene deposits. The non-marine Miocene Mill Creek Formation lies exclusively north of the San Andreas Fault and does not underlie the Yucaipa groundwater subbasins. To the south of the Yucaipa plain in the San Timoteo badlands, grouped units consist of the late Miocene Mt. Eden beds of Frick (Frick, 1921) and Pliocene to mid-Pleistocene members of the San Timoteo Formation (Frick, 1921; Matti and Morton, 1993). Although they are exposed south of the Banning Fault, this fault is likely to have terminated slip before deposition of these formations (Matti and Morton, 1993), and these formations are likely to underlie the Yucaipa groundwater subbasins. Although these deposits have considerable lithologic variability, they are similar in their degree of compaction and cementation relative to younger sedimentary material.

\section{Younger Sedimentary Deposits (Osu)}

Materials grouped in the younger sedimentary deposits (Qsu) represent the upper member of the San Timoteo beds of Frick (Frick, 1921; Rewis and others, 2006); this unit has recently been reassigned by Matti and others (in review) to "Sedimentary deposits of Live Oak Canyon" because it developed in a synclinal trough north of the San Timoteo Badlands about 1.2 million years ago. This deposit forms a thick, sedimentary sequence that is extensive in the subsurface of the Beaumont and Cherry Valley storage units to the south (Rewis and others, 2006). In the study area, this lumped geologic unit is primarily south of the Banning Fault and in the western part of the Yucaipa groundwater subbasins (fig. 2). This deposit is medium- to thick-bedded, moderately to well sorted, moderately indurated, very fine- to coarse-grained sandstone interlayered with subordinate pebbly sandstone and pebble to small-cobble gravel.

\section{Quaternary Surficial Deposits (Qvo, 0oa, Oya, Qvy, and Qls)}

During approximately the last 0.5 million years, multiple cycles of deposition and erosion shaped the modern landscape. Sedimentary deposits that accumulated during these cycles are referred to as surficial materials because they are at the land surface or in the shallow subsurface. Where exposed, they are closely associated with landforms that include incised channels, alluvial-fan cones, and elevated terraces along active stream channels. The materials are lithologically diverse, but are characterized by a common trait-they largely are unconsolidated - that is, they have not been converted to consolidated sedimentary rock through the processes of compaction and cementation. Most of the alluvial deposits are composed of several units ranging in age from early Pleistocene (very old alluvium) to Holocene age (very young alluvium) (Matti, 2003). The very old deposits (Qvo) are of early to middle Pleistocene age, and the older alluvial deposits (Qoa) are middle to late Pleistocene. Subsequent erosion of these moderately to well-consolidated deposits has resulted in deeply incised streambeds, such as the channels of Oak Glen and Yucaipa Creeks. Isolated deposits of slightly consolidated younger alluvium (Qya) border parts of the stream channels and badlands. Unconsolidated very young alluvium (Qvy) is in stream channels throughout the Yucaipa plain and is at its greatest extent in the Western Heights subbasin. Landslide deposits (Q1s) of late to middle Pleistocene age and late Holocene age are in the San Bernardino Mountains northeast of Crafton Hills and near the San Timoteo Canyon.

\section{Data Sets}

\section{Wells}

Depth-to-bedrock and total drill-depth data for production, irrigation, and multiple-well monitoring sites (drilled by the USGS) were used for this study. The driller' logs for 51 water wells (table 1 ; fig. 3 ) were used to constrain and evaluate the gravity interpretations. Fifteen wells (highlighted on table 1) were considered to have penetrated basement rocks on the basis of the descriptions from drillers' logs and were used in the gravity inversion (see the following section). Cores (fig. 4) collected from the bottom of two multiple-well monitoring sites (well 10 drilled in June 1998 and well 28 drilled in June 2003; table 1; fig. 3) showed they penetrated 
basement rocks. Logs and other data for the multiple-well monitoring sites are available on the Yucaipa Project web page (http://ca.water.usgs.gov/yucaipa/).

Reported depths-to-basement rock in driller logs have uncertainties and are not always an accurate reflection of the true depth to bedrock. Boulder and cobble layers in unconsolidated sediments can be difficult to discern from a basementrock surface and can result in reported basement depths shallower than actual ones. Conversely, weathered bedrock can be difficult to distinguish from overlying semi-consolidated alluvium. Based on available data, the depth-to-basement rock at these locations are likely to be between what was reported by the driller's log and the depth estimated by the alluvialthickness model.

\section{Gravity Survey and Reduction}

Gravity measurements were made in 2009 at 256 new locations along 20 profiles in the Yucaipa Basin, totaling approximately $104.6 \mathrm{~km}$ (65 mi) of line distance (fig. 5). Gravity measurements were collected at a station spacing of approximately every 0.3 or $0.8 \mathrm{~km}(0.2$ or $0.5 \mathrm{mi})$. The primary gravity base station used for this survey was PB0508 (Roberts and Jachens, 1986), which is approximately $19.3 \mathrm{~km}$ (12 mi) southeast of Yucaipa, in Bogart County Park, north of Beaumont, California. Location data were collected at all gravity-measuring points by using a Trimble ${ }^{\circledR} 4400$ Real Time Kinematic (RTK) Global Positioning System (GPS) with a TSC-1 data controller. The RTK system was used because of the poor vertical accuracy of a standard GPS. The RTK system uses radio communication to broadcast realtime corrections from the base station to a mobile (rover) receiver to adjust variances to both $\mathrm{X} / \mathrm{Y}$, and $\mathrm{Z}$ locations at the rover position. An accurate elevation at the measuring point is critical for gravity data because of the large error introduced by uncertainty in this value. This system is capable of obtaining vertical and horizontal coordinates at a precision of plus or minus $( \pm) 0.083 \mathrm{ft}$ between receiver and base by using traditional RTK methods described by Morton and others (1993). The RTK survey was referenced to the North American Vertical Datum of 1988 (NAVD88) by using continuously operating reference stations for Online Positioning User Service processing. Local benchmarks were occupied as a secondary reference.

The GPS data were exported and processed by using Trimble $^{\circledR}$ Survey Office version 1.52 by Trimble ${ }^{\circledR}$ Navigation Systems Ltd. The gravity measurements were collected by using a LaCoste and Romberg (L\&R) model D-79 with an Aliod 100 gravity meter connected by serial cable to a Garmin ${ }^{\circledR}$ iQue model 3200 PDA. Raw gravity data were processed by using GravMaster version 1.43 by Geotools Corporation. The primary gravity base station used for this survey was PB0508 (Roberts and Jachens, 1986), which is approximately $12 \mathrm{mi}$ southeast of Yucaipa, in Bogart County Park, north of Beaumont, California. Five data collection loops were completed from PB0508 with differences less than 0.018 milli-Galileo (mGal) to establish a new, temporary gravity base (YGB) in the study area.
These data supplemented 384 previous gravity measurements (Snyder and others, 1982; Langenheim and others, 2006). Gravity data were processed to complete Bouguer gravity anomalies by using standard gravity corrections (Telford and others, 1990) that include (a) earth-tide corrections, (b) instrument-drift corrections, (c) latitude-longitude corrections, (d) free-air corrections, (e) Bouguer correction, (f) curvature corrections, and (g) terrain corrections. Gravity data were reduced by using the Geodetic Reference System of 1967 (International Union of Geodesy and Geophysics, 1971) and referenced to the International Gravity Standardization Net 1971 gravity datum (Morelli, 1974, p. 18). An isostatic correction was applied to the complete Bouguer gravity anomaly value to remove the long-wavelength gravitational effect of isostatic compensation of the crust due to topographic loading. The isostatic correction used a sea-level crustal thickness of 25 kilometers $(\mathrm{km})$, or $16 \mathrm{mi}$; a crustal density of 2,670 kilograms per cubic meter $\left(\mathrm{kg} / \mathrm{m}^{3}\right)$; and a mantle-crust density contrast of $400 \mathrm{~kg} / \mathrm{m}^{3}$ (Langenheim, 2006). The data were gridded at a spacing of 200 meter (m), or $656 \mathrm{ft}$, roughly the spacing of gravity stations along the detailed profiles, by using a minimum curvature algorithm (Briggs, 1974). The resulting gravity field is termed the isostatic residual gravity anomaly (fig. 5).

Local terrain corrections were computed to a radial distance of $167 \mathrm{~km}(104 \mathrm{mi})$ and involved a three-part process: (1) Hayford-Bowie zones A and B with an outer radius

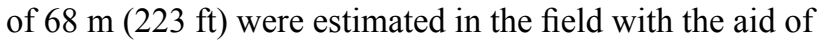
tables and charts; (2) Hayford-Bowie zones C and D with an outer radius of $590 \mathrm{~m}$ were computed by using a $30 \mathrm{~m}$ digital elevation model; and (3) terrain corrections from a distance of $590 \mathrm{~m}$ to $167 \mathrm{~km}(1,936 \mathrm{ft}$ to $104 \mathrm{mi})$ were calculated by using a digital elevation model and a procedure by Plouff (1977). Total terrain corrections for the stations measured for this study ranged from 2.0 to $9.6 \mathrm{mGal}$, averaging $3.4 \mathrm{mGal}$. If the error resulting from the terrain correction is 5 to 10 percent of the total terrain correction, the largest error from the terrain correction expected for the data would be $1.0 \mathrm{mGal}$. The error resulting from the terrain correction was small (less than $0.5 \mathrm{mGal}$ ) for most of the stations, however, because there are minimal differences in relief among most of the stations.

\section{Gravity Field}

The gravity field of the study area (here expressed as the isostatic residual gravity field) is complex and reflects the density contrast between the dense basement complex and the less dense valley-fill deposits (fig. 5). The most prominent features on the gravity map are the high gravity values (greater than $-28 \mathrm{mGal}$ ) that coincided with basement exposures in the Yucaipa and Crafton Hills and the relatively low gravity values (less than $-30 \mathrm{mGal}$ ) that coincided with the valley-fill deposits of the Yucaipa Valley. The lowest gravity values (less than $-38 \mathrm{mGal}$ ) coincided with previous measurements made in the badlands south of the Banning fault zone and delineate the Beaumont Basin, which likely contains mostly older consolidated Cenozoic sedimentary rocks (Langenheim and others, 2005). 
Table 1. State well number, station identification, local name, location, bore-hole depth, and depth-to-basement rocks for selected wells in the Yucaipa area, California.

[See figure 2 for site locations. State well number, see "Well-Numbering System" in front of report. Highlighted rows are wells considered to penetrate bedrock. Abbreviations: BLSD, below land surface datum; bw, below well; ft, feet; NAD, North American Datum; nd, no data; SMWC, South Mesa Water company; USGS, U.S. Geological Survey; WHWC, Western Heights Water Company; YV6E, Yucaipa Valley 6th and E Street; YVDA, Yucaipa Valley Dunlap Acres; YVEP, Yucaipa Valley Equestrian Park; YVWC, Yucaipa Valley Wilson Creek; YVWD, Yucaipa Valley Water District]

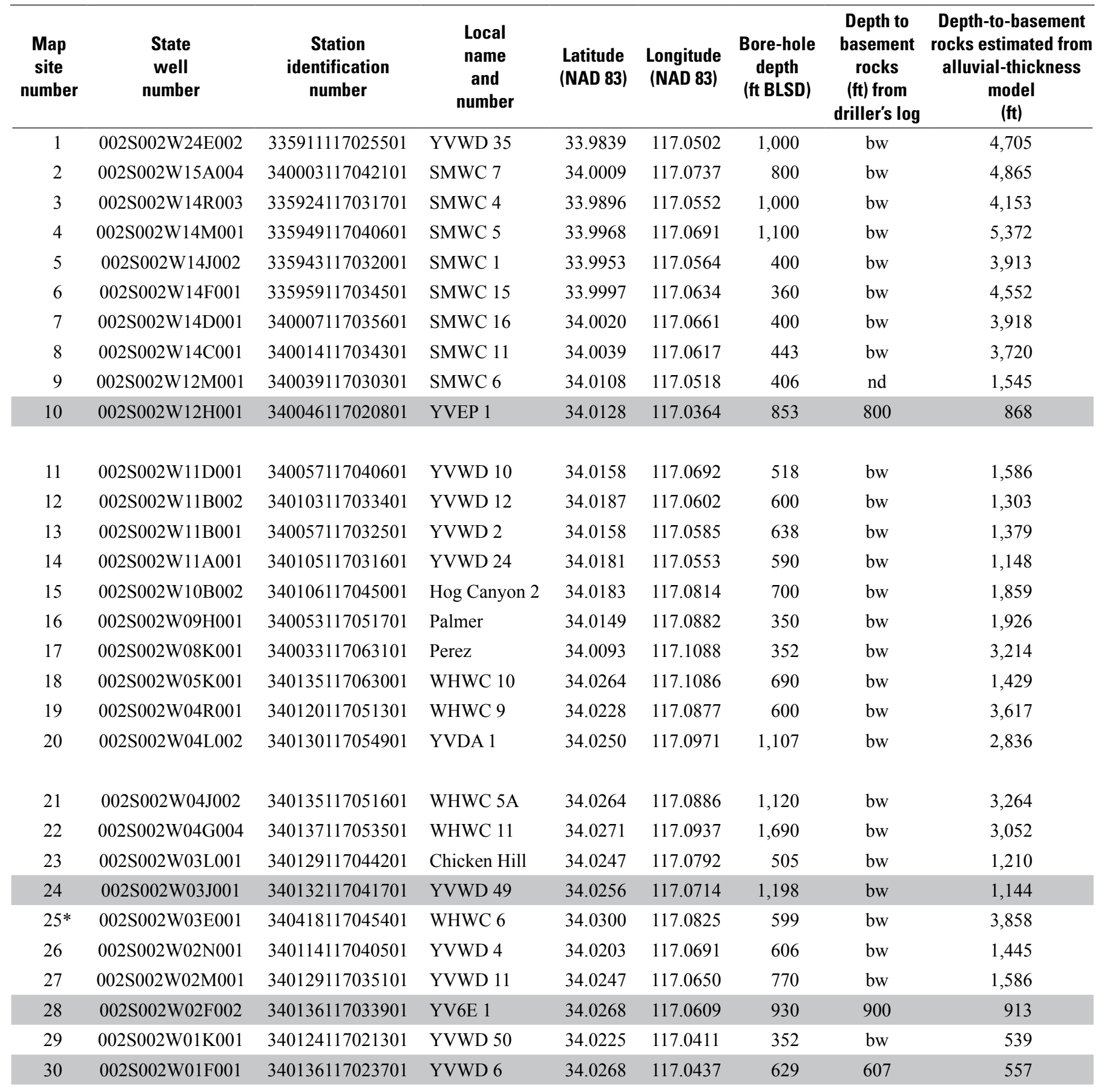


Table 1. State well number, station identification, local name, location, bore-hole depth, and depth-to-basement rocks for selected wells in the Yucaipa area, California.-Continued

[See figure 2 for site locations. State well number, see "Well-Numbering System" in front of report. Highlighted rows are wells considered to penetrate bedrock. Abbreviations: BLSD, below land surface datum; bw, below well; ft, feet; NAD, North American Datum; nd, no data; SMWC, South Mesa Water company; USGS, U.S. Geological Survey; WHWC, Western Heights Water Company; YV6E, Yucaipa Valley 6th and E Street; YVDA, Yucaipa Valley Dunlap Acres; YVEP, Yucaipa Valley Equestrian Park; YVWC, Yucaipa Valley Wilson Creek; YVWD, Yucaipa Valley Water District]

\begin{tabular}{|c|c|c|c|c|c|c|c|c|}
\hline $\begin{array}{c}\text { Map } \\
\text { site } \\
\text { number }\end{array}$ & $\begin{array}{c}\text { State } \\
\text { well } \\
\text { number }\end{array}$ & $\begin{array}{c}\text { Station } \\
\text { identification } \\
\text { number }\end{array}$ & $\begin{array}{l}\text { Local } \\
\text { name } \\
\text { and } \\
\text { number }\end{array}$ & $\begin{array}{l}\text { Latitude } \\
\text { (NAD 83) }\end{array}$ & $\begin{array}{l}\text { Longitude } \\
\text { (NAD 83) }\end{array}$ & $\begin{array}{c}\text { Bore-hole } \\
\text { depth } \\
\text { (ft BLSD) }\end{array}$ & $\begin{array}{l}\text { Depth to } \\
\text { basement } \\
\text { rocks } \\
\text { (ft) from } \\
\text { driller's log }\end{array}$ & $\begin{array}{l}\text { Depth-to-basement } \\
\text { rocks estimated from } \\
\text { alluvial-thickness } \\
\text { model } \\
\text { (ft) }\end{array}$ \\
\hline 31 & 002S001W09G001 & 340041117592001 & YVWD 28 & 34.0124 & 116.9916 & 606 & 420 & 216 \\
\hline 32 & 002S001W08F001 & 340054117002901 & YVWD 27 & 34.0148 & 117.0110 & 314 & 300 & 156 \\
\hline 34 & 001S002W36R001 & 340214117020901 & YVWD 7 & 34.0372 & 117.0367 & 695 & 545 & 567 \\
\hline 35 & 001S002W36N001 & 340215117025701 & YVWD 5 & 34.0375 & 117.0492 & 523 & bw & 970 \\
\hline 36 & 001S002W36G001 & 340236117023101 & YVWD 46 & 34.0433 & 117.0428 & 1,150 & bw & 1,182 \\
\hline 37 & 001S002W36F004 & 340239117024801 & YVWD 56 & 34.0443 & 117.0476 & 1,100 & bw & 880 \\
\hline 38 & 001S002W36F001 & 340233117023501 & YVWD 18 & 34.0429 & 117.0444 & 596 & bw & 1,116 \\
\hline 41 & 001S002W25R004 & 340255117021601 & YVWD 53 & 34.0486 & 117.0386 & 1,220 & 1,220 & 987 \\
\hline 42 & 001S002W25M002 & 340316117025201 & YVWD 9 & 34.0547 & 117.0467 & 780 & 154 & 169 \\
\hline 43 & 001S002W25A001 & 340343117021201 & YVWD 37 & 34.0620 & 117.0375 & 468 & nd & 267 \\
\hline 44 & 001S002W13P001 & 340443117023501 & Mill Creek 1 & 34.0786 & 117.0431 & 168 & bw & 262 \\
\hline 45 & 001S001W32C001 & 340253117002701 & YVWD 13 & 34.0480 & 117.0083 & 415 & 186 & 62 \\
\hline 46 & 001S001W32A001 & 340249116595601 & YVWD 14 & 34.0470 & 116.9994 & 160 & 39 & 5 \\
\hline 47 & 001S001W30N001 & 340257117015301 & USGS 2 & 34.0492 & 117.0314 & 500 & bw & 932 \\
\hline $48^{*}$ & 001S001W30G001 & 340328117012801 & YVWD 22 & 34.0578 & 117.0244 & 550 & bw & 1,049 \\
\hline
\end{tabular}

*Well is destroyed. 

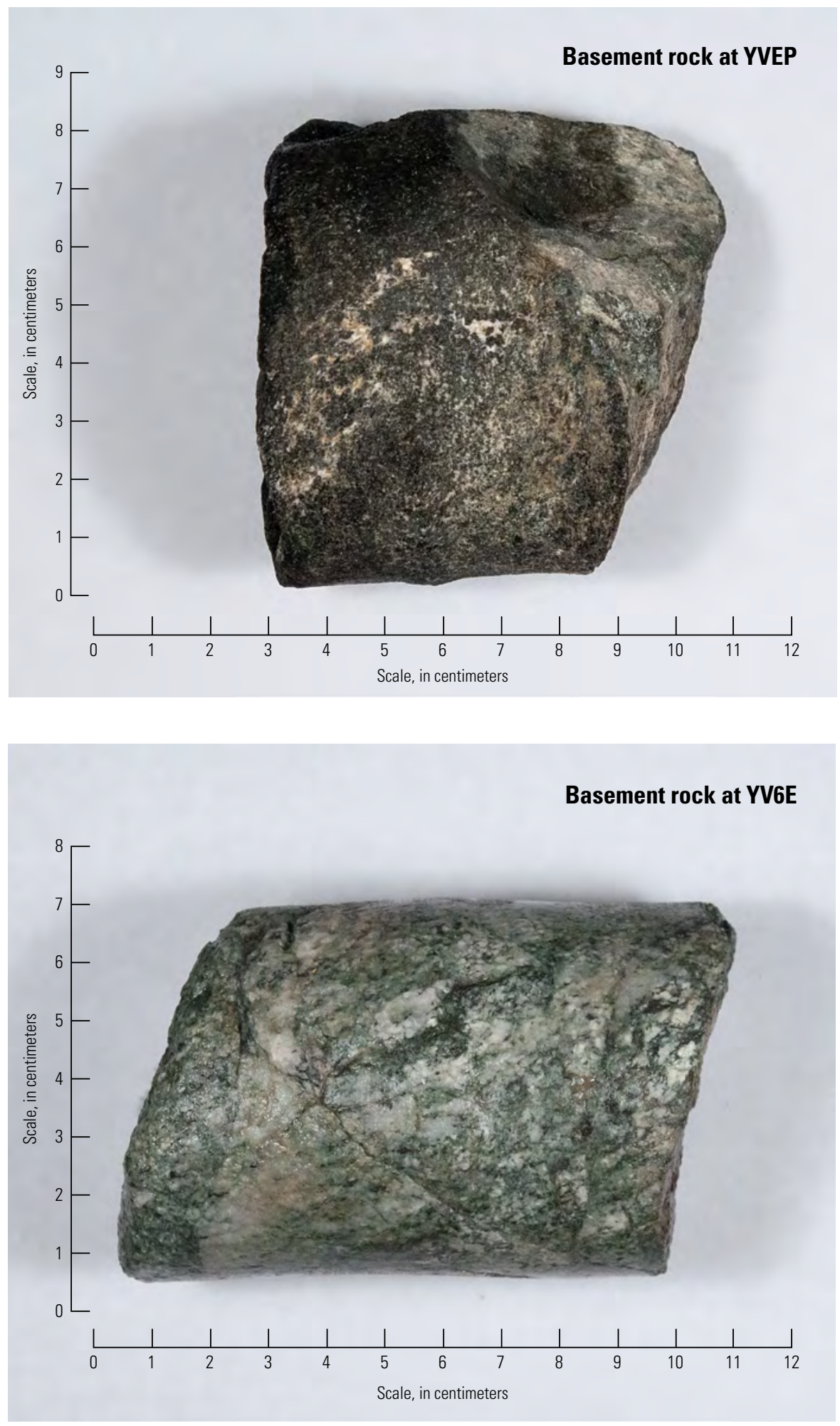

Figure 4. Basement rock at map site 10 and 28 on table 1 (YVEP and YV6E) in the Yucaipa area, California. 


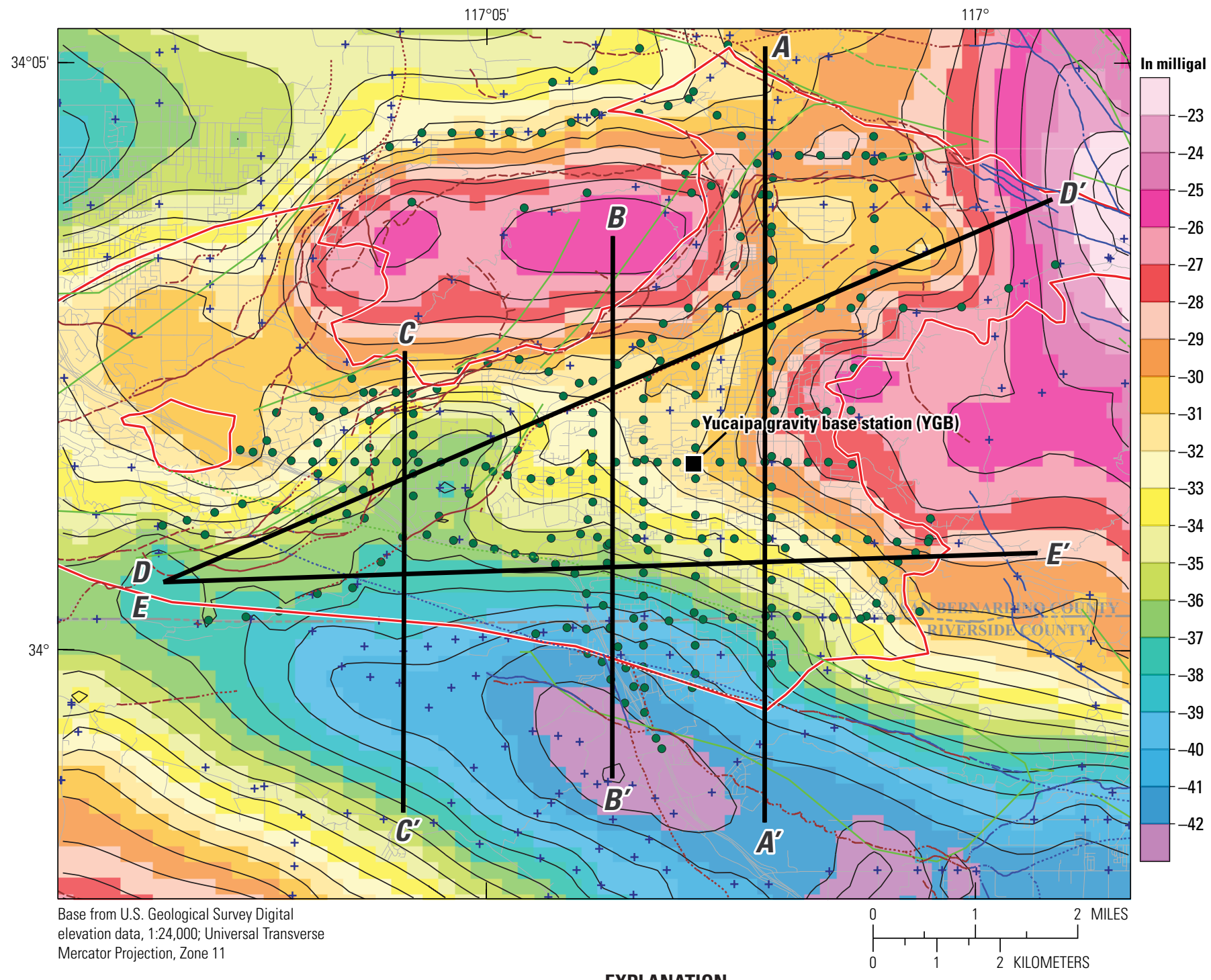

EXPLANATION

California Department of Water Resources (DWR) groundwater subbasin boundary—Upper Santa Ana Valley,

Yucaipa subbasins, California Department of Water Resources, 2004; Bulletin 118-updated 2003.

Fault-Solid where accurately located; dashed where approximately located; dotted where concealed (Morton and Miller, 2006).

Fault-Solid where accurately located; dashed where approximately located; dotted where concealed (Matti and others, 2003).

Fault-Solid where accurately located; dashed where approximately loc ated; dotted where concealed (California Division of

$\begin{array}{ll}\boldsymbol{A}-\boldsymbol{A}^{\prime} & \begin{array}{l}\text { Mines and Geology, 2000). } \\ \text { Profile line-Letter designation is profile name, figure } 7 . \\ \text { New gravity station } \\ \text { Old gravity station }\end{array}\end{array}$

Figure 5. Isostatic residual gravity field in the Yucaipa area, California. 


\section{Computation Method for Modeling the Thickness of the Valley-Fill Deposits}

The thickness of the valley-fill deposits (or depth-tobasement rock) throughout the study area was estimated by using the method of Jachens and Moring (1990), modified slightly to permit inclusion of constraints at points where the thickness of the valley-fill deposits was known from direct observations in boreholes. An initial estimate of the 'valleyfill deposits gravity anomaly' was made by passing a smooth surface through the gravity values at stations where the basement complex rocks crop out (initial estimate of the 'basement gravity field') and subtracting this from the isostatic residual gravity field. This represents only the initial estimate, because the gravity values at points on basement rocks that lie close to the valley-fill deposits were influenced by the lower density valley-fill deposits and are, therefore, less than they would be if the valley-fill deposits were not present. To compensate for this effect, the initial 'valley-fill deposits gravity anomaly' was used to calculate an initial estimate of the thickness of the valley-fill deposits, and the gravity effect of these valley-fill deposits was calculated at all of the basement gravity stations. A second estimate of the 'basement gravity field' was then made by passing a smooth surface through the basement gravity values corrected by the valley-fill effect. This process was repeated again until further steps did not result in large changes to the modeled thickness of the valley-fill deposits (usually five or six steps). The 'valley-fill deposits gravity anomaly' was converted to thickness of the valley-fill deposits (fig. 6) by using an assumed density contrast that varied with depth between the sedimentary deposits that make up the valley-fill deposits and the underlying basement rocks (table 2; Langenheim, 2006). The youngest surficial units were constrained to the upper layer of the assumed density-depth relationship, although this layer could incorporate older surficial units that are exposed or shallowly concealed beneath a veneer of younger deposits.

The prominent features on the valley-fill map are the 3,000-ft depression that coincides with the Western Heights subbasin and the deep depressions (over 7,000 ft) south of the Banning fault zone.

\section{Depth-to-Basement Profiles}

Five depth-to-basement profiles (figs. 7A-E) were created for the Yucaipa area by using the basement rock data and digital elevation model. The profile transects were designed to pass through or come close to the multiple-well monitoring sites (fig. 6) because these wells have better lithologic information than most production wells in the study area. Subbasin boundaries (Moreland, 1970) and faults from several sources (California Division of Mines and Geology, 2000; Matti and
Table 2. Assumed density contrast with depth in the Yucaipa area, California.

[BLS, below land-surface datum; $\mathrm{ft}$, feet; $\mathrm{kg} / \mathrm{m}^{3}$, kilogram per cubic meter; $\mathrm{m}$, meters; >, greater than]

\begin{tabular}{ccc}
\hline $\begin{array}{c}\text { Depth range } \\
\text { (ft BLS) }\end{array}$ & $\begin{array}{c}\text { Depth range } \\
\text { (m BLS) }\end{array}$ & $\begin{array}{c}\text { Density contrast } \\
\left(\mathbf{k g} / \mathbf{m}^{\mathbf{3}}\right)\end{array}$ \\
\hline $0-328$ & $0-100$ & -500 \\
$328-656$ & $100-200$ & -400 \\
$656-1,968$ & $200-600$ & -360 \\
$1,968-4,920$ & $600-1,500$ & -300 \\
$>4,920$ & $>1,500$ & -230 \\
\hline
\end{tabular}

others, 2003; Morton and Miller, 2006) were added to the profiles to correlate modeled basement offsets with different fault sources. In general, vertical or steeply dipping faults where there are large offsets of material of varying density have steep gravity gradients and generate large differences in modeled alluvial thickness. An example is shown along the southern part of the Crafton Hills and south of the Crafton Hills fault zone (fig. 6). The orientation of faults that are oblique to, or follow the profile are difficult to show on a two dimensional profile, so both the profile and plan view should be used for interpretation.

Profile $A-A^{\prime}$ starts near the San Andreas fault zone, traverses the eastern portion of the Yucaipa valley, and terminates south of the Cherry Valley strand of the San Gorgonio Pass fault zone (fig. 7A). The profile spans five subbasins and crosses five faults at various angles, including intersecting the western edge of the Yucaipa Graben Complex, where it meets the Crafton Hills fault zone. The profile goes through one multiple-well monitoring site and near three production wells that penetrate the basement complex. From north to south, prominent changes in bedrock elevation include a drop in the basement surface of about $800 \mathrm{ft}$ near the Yucaipa Graben Complex and then a 250-ft rise to the Gateway Barrier, marking the northern edge of the Wilson Creek subbasin. South of this barrier in the Wilson Creek subbasin, the basement surface drops about $400 \mathrm{ft}$ and then climbs $800 \mathrm{ft}$ to a basement high where the Casa Blanca and South Mesa barriers mark the boundaries with the Oak Glenn and Calimesa subbasins, respectively. Profile $A-A^{\prime}$ depicts an irregular, but gradually dipping, basement surface beneath the Calimesa subbasin; one irregularity is an abrupt drop in the surface of about $700 \mathrm{ft}$, which is associated with an unnamed fault identified by the California Division of Mines and Geology (2000).

Profile $B-B^{\prime}$ starts in the Crafton Hills, traverses the central part of Yucaipa Valley, and terminates south of the Cherry Valley strand of the San Gorgonio Pass fault zone (fig. $7 B$ ). The profile crosses six faults at various angles and includes the Crafton and Calimesa subbasins. This profile starts in exposures of the basement rocks and, at the Crafton Hills fault zone, passes into sedimentary fill of the Yucaipa Basin. This 


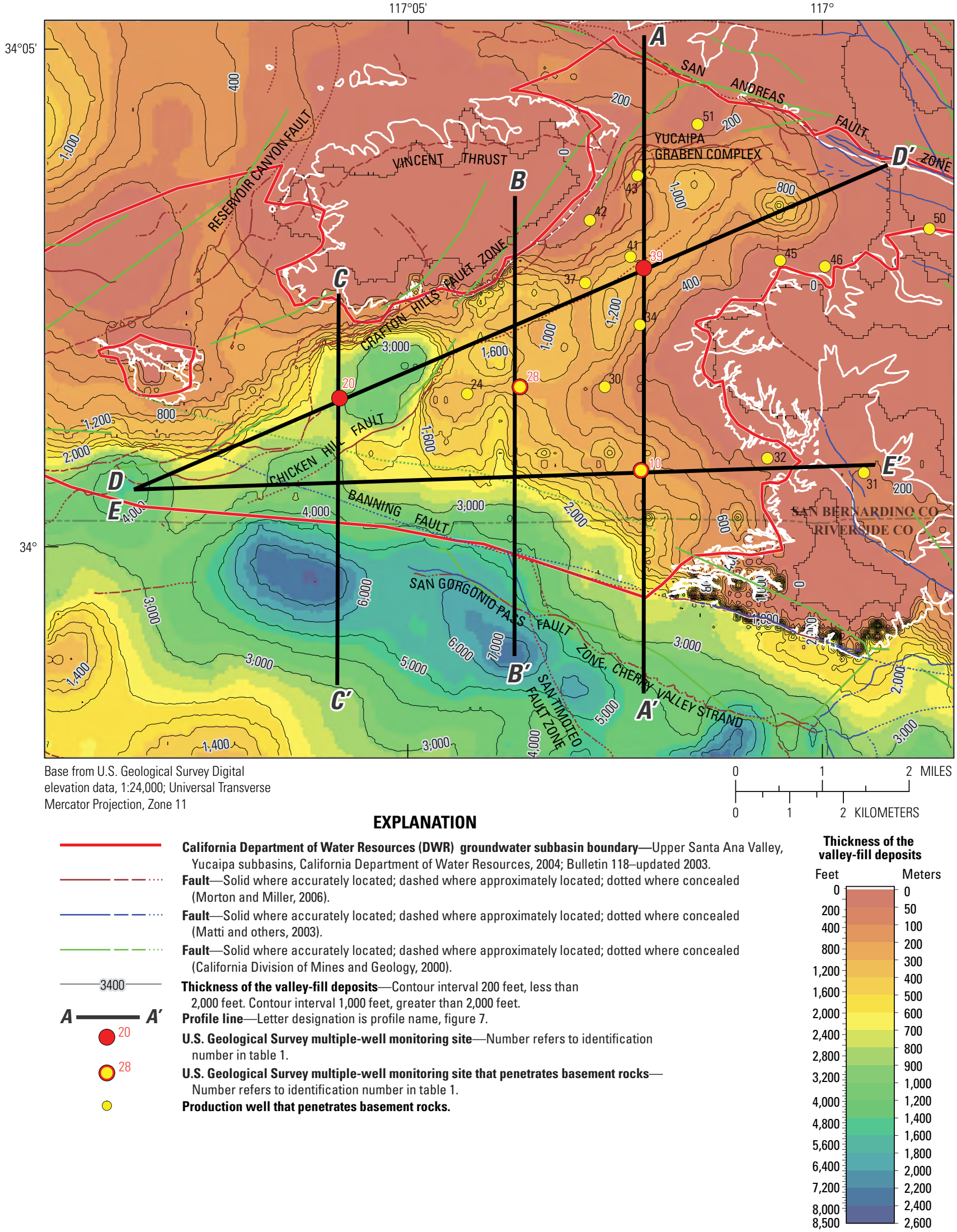

Figure 6. Estimated thickness of the valley-fill deposits in the Yucaipa area, California. 


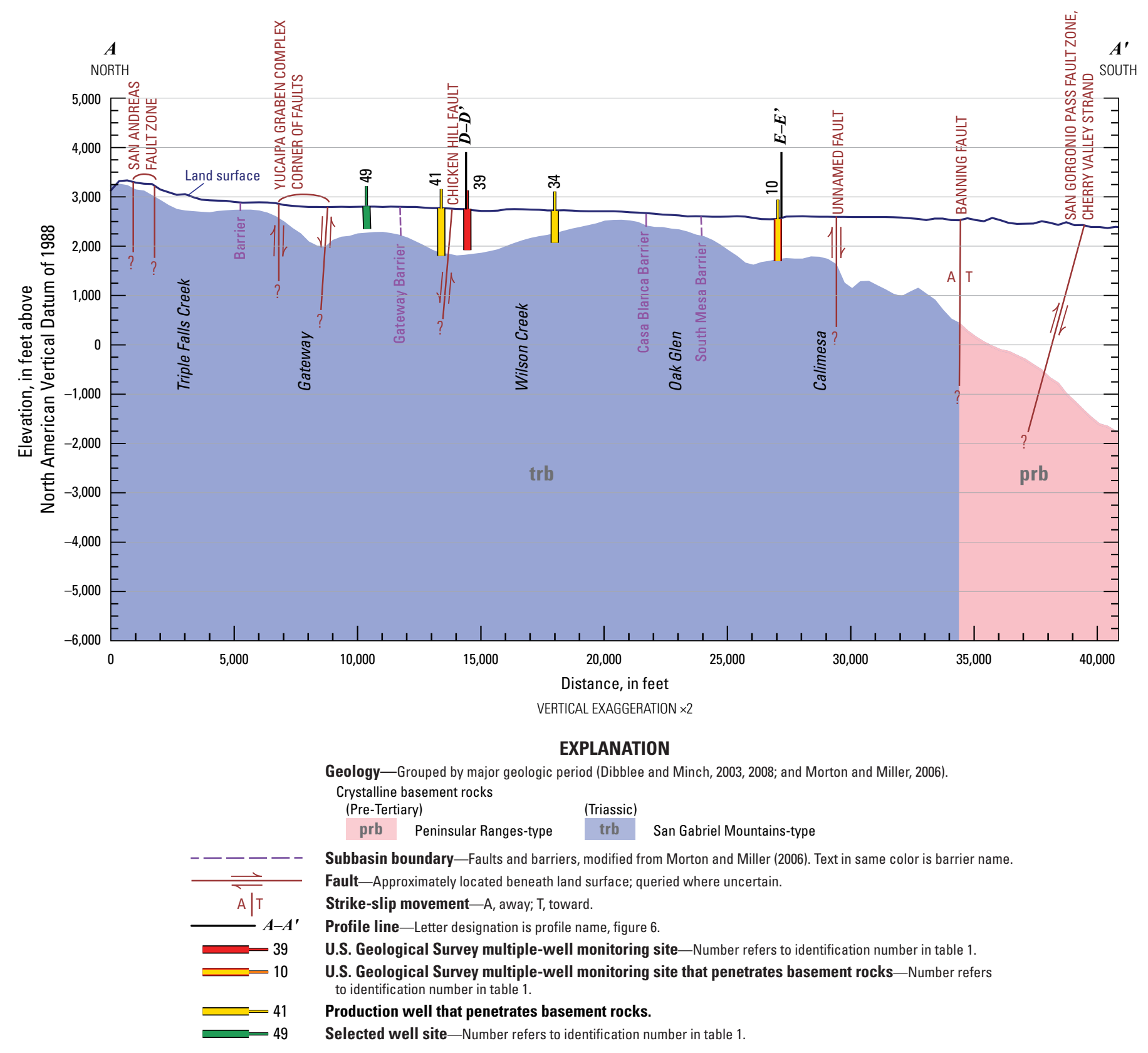

Figure 7A. Schematics showing five profiles in the Yucaipa area, southern California. Profile line $A-A$ '. 


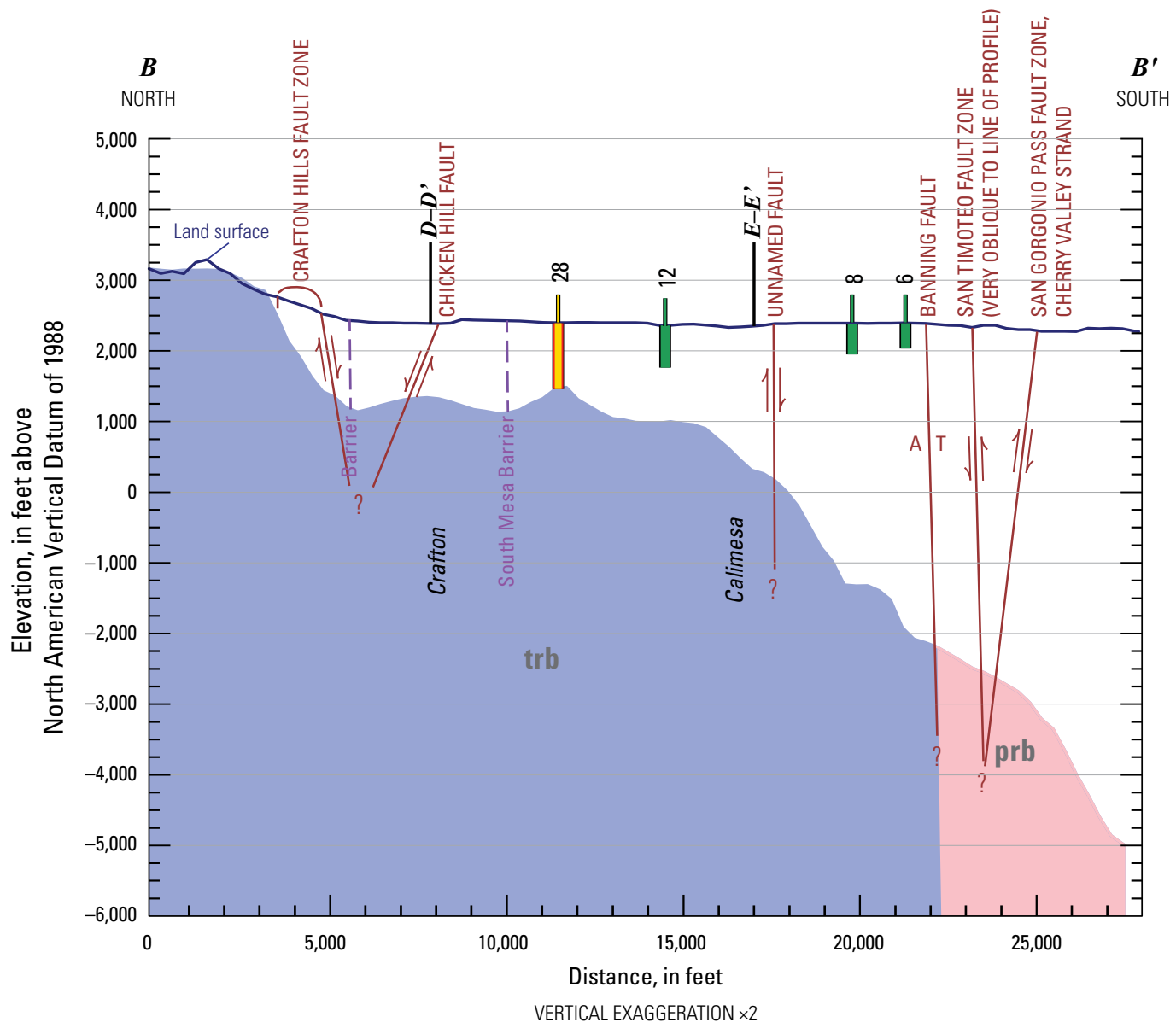

\section{EXPLANATION}

Geology-Grouped by major geologic period (Dibblee and Minch, 2003, 2008; and Morton and Miller, 2006). Crystalline basement rocks
(Pre-Tertiary)
(Triassic)
prb Peninsular Ranges-type trb San Gabriel Mountains-type

\footnotetext{
Subbasin boundary-Faults and barriers, modified from Morton and Miller (2006). Text in same color is barrier name. Fault-Approximately located beneath land surface; queried where uncertain. Strike-slip movement-A, away; T, toward.

Profile line-Letter designation is profile name, figure 6 .

U.S. Geological Survey multiple-well monitoring site that penetrates basement rocks-Number refers to identification number in table 1.

Selected well site_-Number refers to identification number in table 1.
}

Figure 7B. Schematics showing five profiles in the Yucaipa area, southern California. Profile line $B-B^{\prime}$. 

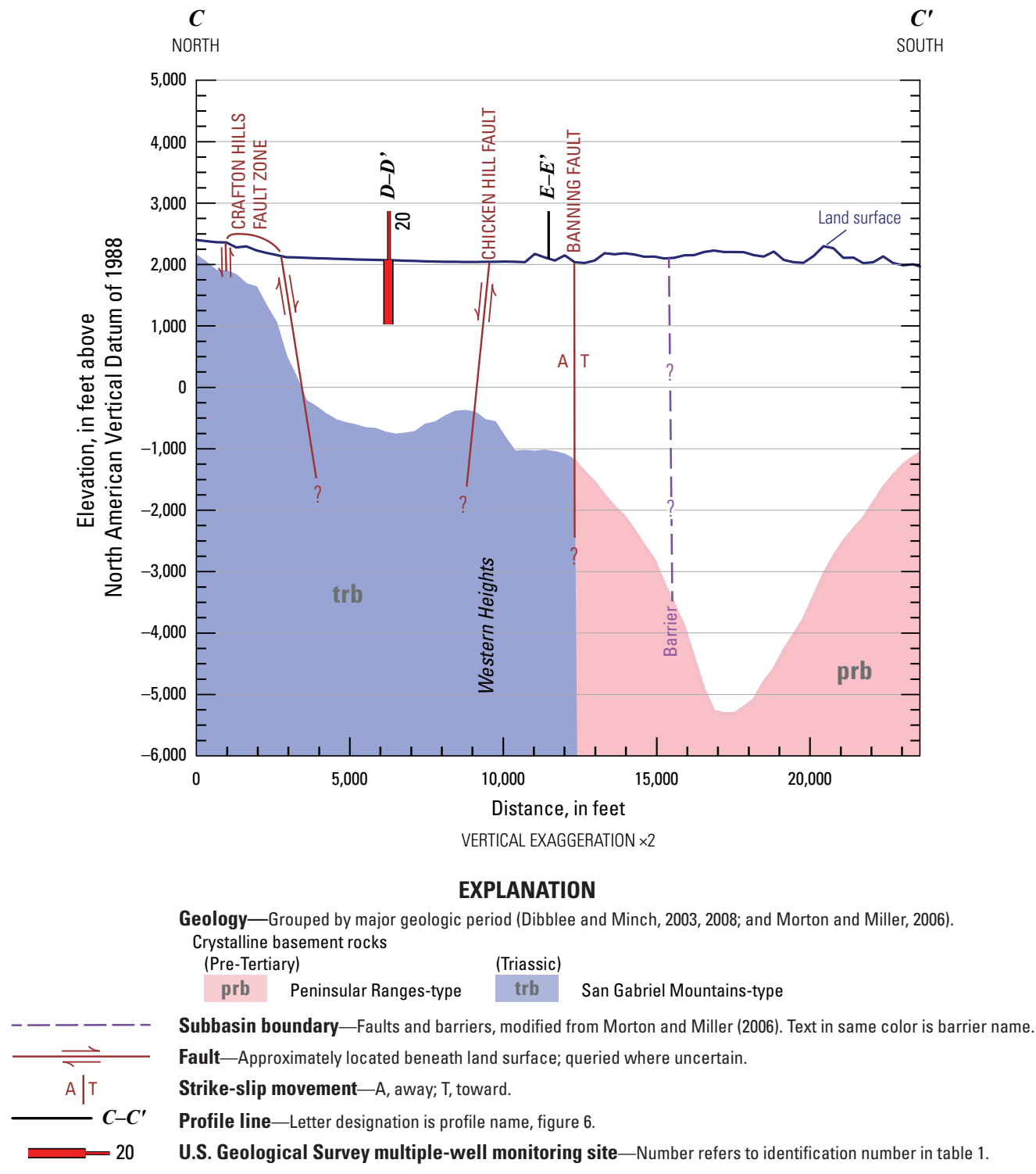

Figure 7C. Schematics showing five profiles in the Yucaipa area, southern California. Profile line $C-C$. 


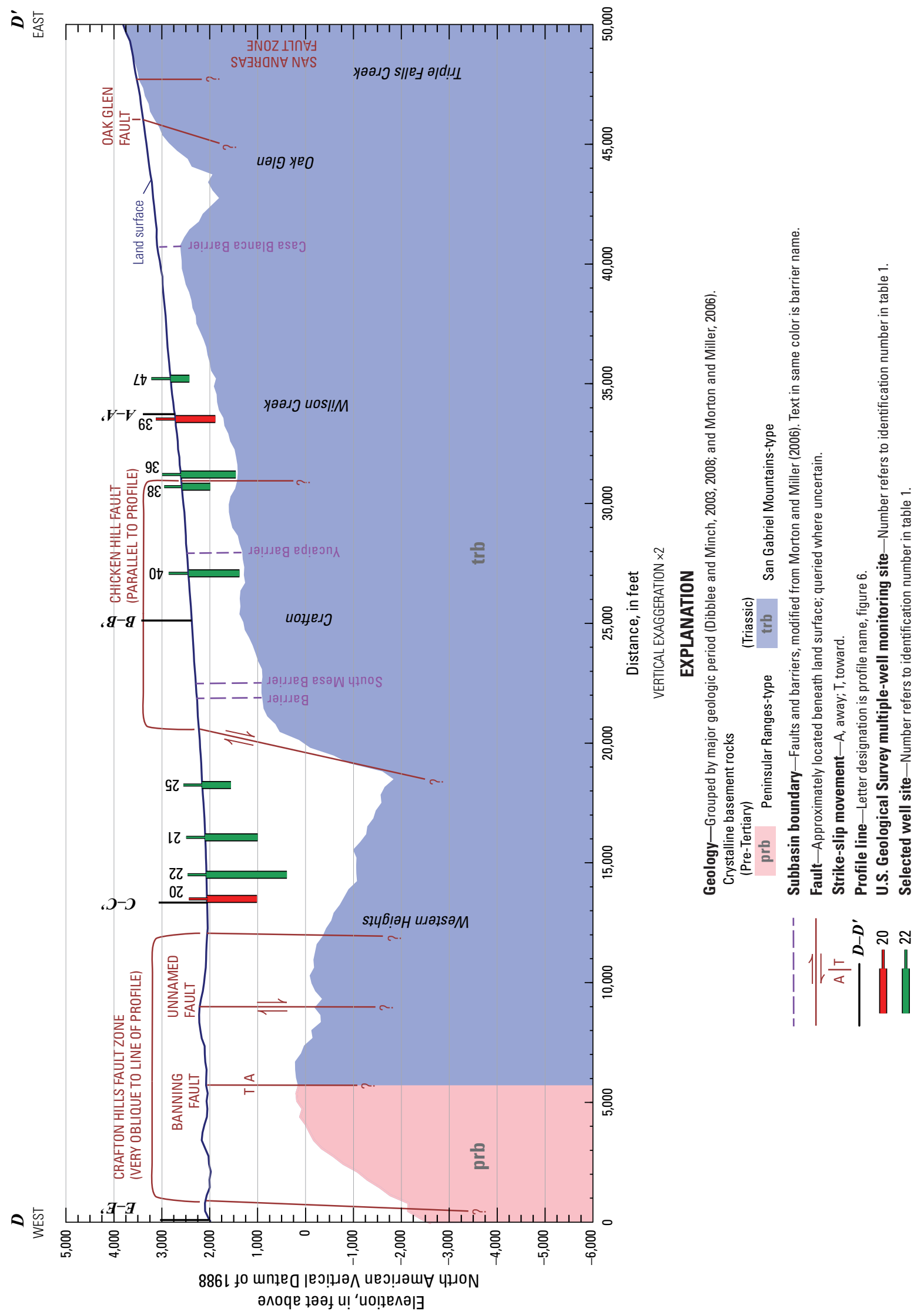




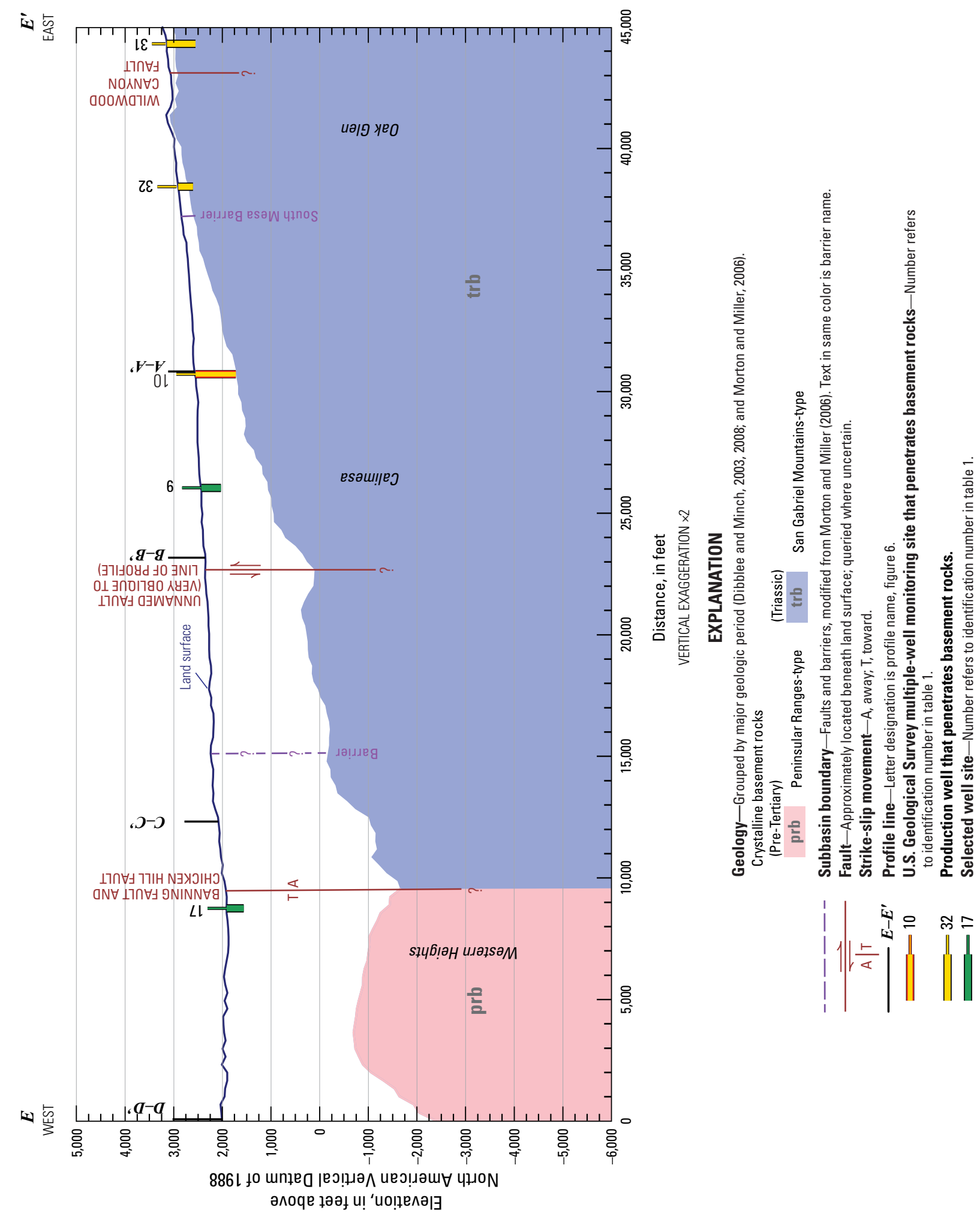

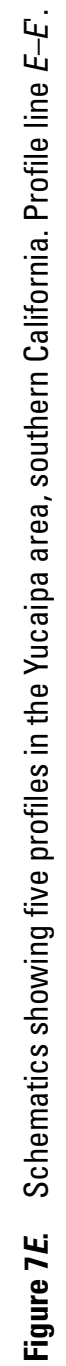


profile passes through a multiple-well monitoring site that terminates in basement rocks (well 28) and continues south near three production wells that do not encounter basement rocks (wells 6, 8, and 12). Near the northern end of the profile, the Crafton Hills fault zone coincides with a drop in the basement surface of about 2,000 ft to the south, followed by a gentle rise of about $200 \mathrm{ft}$ to the Chicken Hill Fault. In the vicinity of well 28 (table 1), the basement surface shows a 300-ft hump (fig. $7 B$ ), which is the concealed westward extension of the crystalline rocks exposed in the Yucaipa Hills. South of the Banning Fault, gravity data indicated that the basement surface drops $6,000 \mathrm{ft}$, relative to site 28 , in one of several deep depressions (fig. 6). Langenheim and others (2005) concluded that the gravity low south of the Ban ning Fault in several profiles could correlate to a similar gravity low associated with the thick sedimentary fill at the northwest head of the Salton Trough, and they proposed that the former has been displaced away from the Salton Trough by dextral slip on the old Banning Fault.

Profile $C-C^{\prime}$ begins in the Crafton Hills, traverses the Western Heights subbasin, and terminates near San Timoteo Wash (fig. 7C). The north part of the cross section is anchored in very old alluvium on the uplifted Crafton Hills block. To the south at the Crafton Hills fault zone, the basement surface drops by about 2,000 ft. Southward, the section traverses the Western Heights subbasin, where there is a multiple-well monitoring site (well 20); there are no other wells along section $C-C^{\prime}$. The direction of displacement of the Chicken Hill Fault is uncertain. Surface outcrops to the northeast of profile $C-C^{\prime}$ indicate that the Chicken Hill has down-to-the-north, normal-slip displacement (Matti and others, 2003). However, in section $C-C^{\prime}$, the Chicken Hill Fault appears to coincide with a down-to-the-south drop of the basement surface of about $700 \mathrm{ft}$. The geologic structure is complicated in this area, and it is possible that a down-to-the-north drop along the Chicken Hill Fault was masked by the larger drop to the south of a basement depression. Farther south, section $C-C^{\prime}$ shows the basement surface dropping into a depression deeper than 7,000 ft below land surface; the depression was correlated with a gravity low associated with the thick sedimentary fill at the northwest head of the Salton Trough (Langenheim and others, 2005). This rapid change in depth to basement appears to coincide with the Banning Fault, an old dextral strand of the San Andreas fault system (Matti and others, 1992; Matti and Morton, 1993).

Profile $D-D^{\prime}$ begins southwest of Dunlap acres (fig. 3), traverses the northeastern portion of the valley, and terminates at the San Andreas fault zone (fig. 7D). The profile crosses five subbasins: Western Heights, Crafton, Wilson Creek, Oak Glen, and Triple Falls Creek. It also crosses several faults or barriers at various angles and is parallel to the Chicken Hill Fault in the central part of figure $7 D$. The profile follows the Oak Glen and Wilson Creek channels to the east. The profile passes through two multiple-well monitoring sites (wells 20 and 39; table 1; fig. 3) and passes near seven production wells; none of the driller logs of the wells reported bottom material consistent with basement rocks. From southwest to northeast along profile $D-D^{\prime}$, the basement surface drops about 2,000 ft from the Banning Fault across the Western Heights subbasin to the Chicken Hill Fault, then rises about 2,800 ft across the Crafton subbasin, rises another $500 \mathrm{ft}$ across the Wilson Creek subbasin, and then climbs another 1,200 ft across the Oak Glen subbasin. In the upper Oak Glen subbasin, the basement surface shows a local depression (fig. 7D) that is partially connected to a trough in the basement surface to the west and southwest; this bedrock valley could potentially facilitate groundwater movement to the southwest along Wilson Creek.

Profile $E-E^{\prime}$ begins southwest of Dunlap Acres, traverses the Yucaipa Valley, and terminates in the hills east of Yucaipa (fig. $7 E$ ). The profile crosses three subbasins: Western Heights, Calimesa, and Oak Glen, and crosses four faults (two faults at one location) at various angles. This profile follows the Yucaipa Creek through Wildwood Canyon to the east. The profile passes through a residential well and near four production wells, two of which penetrate the basement rocks (wells 31 and 32), and one multiple-well monitoring site (well 10) that also terminates in the basement rocks. From west to east, the basement surface drops $900 \mathrm{ft}$ to a local low along the Banning and Chicken Hills Faults in the Western Heights subbasin, then climbs $1,500 \mathrm{ft}$ to the barrier at the west edge of the Calimesa subbasin. The basement surface continues to climb about 3,000 ft across the Calimesa subbasin, except for a trough that coincides with an unnamed fault (California Division of Mines and Geology, 2000).

\section{Limitations}

There are basic uncertainties intrinsic to this gravity analysis. Limitations in data collection, processing of the gravity data, and alluvial thickness modeling, indicated that the best resolution that can be expected, even in areas of good gravity coverage, is about $\pm 50 \mathrm{ft}$, and resolution is likely to be less in areas of poor gravity coverage or in areas either far from the basement outcrop or from control points where no wells reporting basement rocks were available. The lack of agreement at any site could also reflect uncertainties from interpretations of lithology from descriptions provided in drillers' logs as well as the spatial averaging of gravity data. Use of the mud-rotary method to drill wells can obscure the cuttings, and it can be difficult to distinguish valley-fill deposits from granite or decomposed granite. Drillers' log data from some wells could incorrectly report basement complex, when actually 
drilling in decomposed granite or a large boulder. Also, spatial averaging in the predicted depth to basement can cause inaccuracies because the calculations were averaged on a $656-\mathrm{ft}$ grid spacing. Results represent averages of the thickness of the valley-fill deposits for the area of the grid cell. Variations in the thickness of valley-fill deposits over distances less than a cell-dimension are not resolvable. Basement location based on the proximity of wells to the western margin of the basin either in the Chicken Hill fault zone or in the Yucaipa Graben Complex might not compare with basement location predicted by the gravity inversion because of spatial averaging. Gravity data reflect the average shape of the causative body (in this case, the thickness of the valley-fill deposits), and the averaging becomes more pronounced farther from the measurements. As a result, places where the valley-fill deposits are the thickest were subject to greater degrees of averaging and, thus, appear smoother than areas where the valley-fill deposits are thinner.

\section{Results}

The alluvial thickness model developed from gravity data for this study yielded an estimated thickness of the valley-fill deposits, or depth-to-basement rocks, ranging from $0 \mathrm{ft}$ in the Crafton Hills and the hills east of Yucaipa to more than $3,000 \mathrm{ft}$ beneath the Yucaipa plain. Valley-fill deposits between the Crafton Hills fault zone and Chicken Hill Fault show a depression of more than $3,000 \mathrm{ft}$, which coincides with the Western Heights subbasin. Basement rocks of the Peninsular Ranges type south of the Banning Fault are more than 7,000 ft beneath land surface.

The depth-to-basement values were reviewed for analytical accuracy and precision by comparing the depth estimates to actual values in wells that penetrate basement rocks. The estimated thickness of the valley-fill deposits at multiple-well monitoring site $2 \mathrm{~S} / 2 \mathrm{~W}-2 \mathrm{~F} 2$ (well 28 in table 1; fig. 3), which penetrates the entire thickness of the valley-fill deposits, disagrees with the observed thickness by $150 \mathrm{ft}$. This disagreement is likely due to the large amount of fractured bedrock in this area. The estimated thickness of the valley-fill deposits at multiple-well monitoring site $2 \mathrm{~S} / 2 \mathrm{~W}-12 \mathrm{H} 1$ (well 20 in table 1; fig. 3), which terminates in the basement complex, agrees with the observed thickness to within $48 \mathrm{ft}$. Electric logs from both of these monitoring wells showed an increase in resistivity where the lithologic logs identified basement rocks. Basement rocks were verified by cores (fig. 4) from the bottom of these two monitoring-well sites. Our gravity-based depth-to-basement estimates did not match the reported values in all cases. We attributed these discrepancies to the paucity of gravity measurements in this area.

Another measure of the reliability of the gravity inversion can be obtained by comparing the estimated thicknesses with the total well depths at those wells that did not penetrate the basement rocks. The estimated thickness of valley-fill deposits at all 36 wells where basement was not encountered was greater than the total well depth at those sites (table 1).

The gravity data and resulting depth-to-basement map provide a new understanding of structures that could influence groundwater flow in the Yucaipa groundwater subbasins. A buried basement structure between the Wilson Creek and Calimesa subbasins that constrains flow between these subbasins is shown in profile $A-A^{\prime}$ (fig. 7A). The toe of this structure can also be seen at well 28 (monitoring well YV6E-1) in profile $B-B^{\prime}$ (fig. $7 B$ ). An unnamed fault (California Division of Mines and Geology, 2000) coincides with a step in the basement surface in profiles $A-A^{\prime}$ to $C-C^{\prime}$. Profile $C-C^{\prime}$ (fig. 7C) shows a 500-ft step in the basement surface near the Chicken Hill Fault and a depression of more than 4,000 ft in the basement surface south of the Banning Fault. Profile $D-D^{\prime}$ (fig. 7D) shows a 2,000-ft drop in the basement surface that then rises 2,800 $\mathrm{ft}$ to the Crafton subbasin. The basement surface climbs 1,200 ft from Wilson Creek to the Oak Glen subbasin. The Oak Glen subbasin shows a large area in the old alluvium where groundwater can flow southwest toward Wilson Creek subbasin. Profile $E-E^{\prime}$ (fig. $7 E$ ) has a 3,000-ft drop in the basement surface in the Calimesa subbasin and another 2,500-ft drop in the basement surface in the Western Heights subbasin.

\section{Animation of Alluvial Thickness Model}

The elevation of the top of the basement rocks was calculated by subtracting the modeled thickness of the valley-fill deposits at each gravity grid node from the average landsurface elevation at that grid node. To help visualize the basin geometry, an animation of the elevation of the top of the basement rocks was developed. The animation allows the viewer to "fly" over the Yucaipa groundwater basin viewing the land surface, geology, faults (color coded as on figs. 1-5), wells in different subbasins in the Yucaipa study area, and the ridges and valleys of the shaded-relief elevation of the top of the basement complex. The animation and associated explanation are shown on fig. 8 (click on fig. 8 to see the animation). 


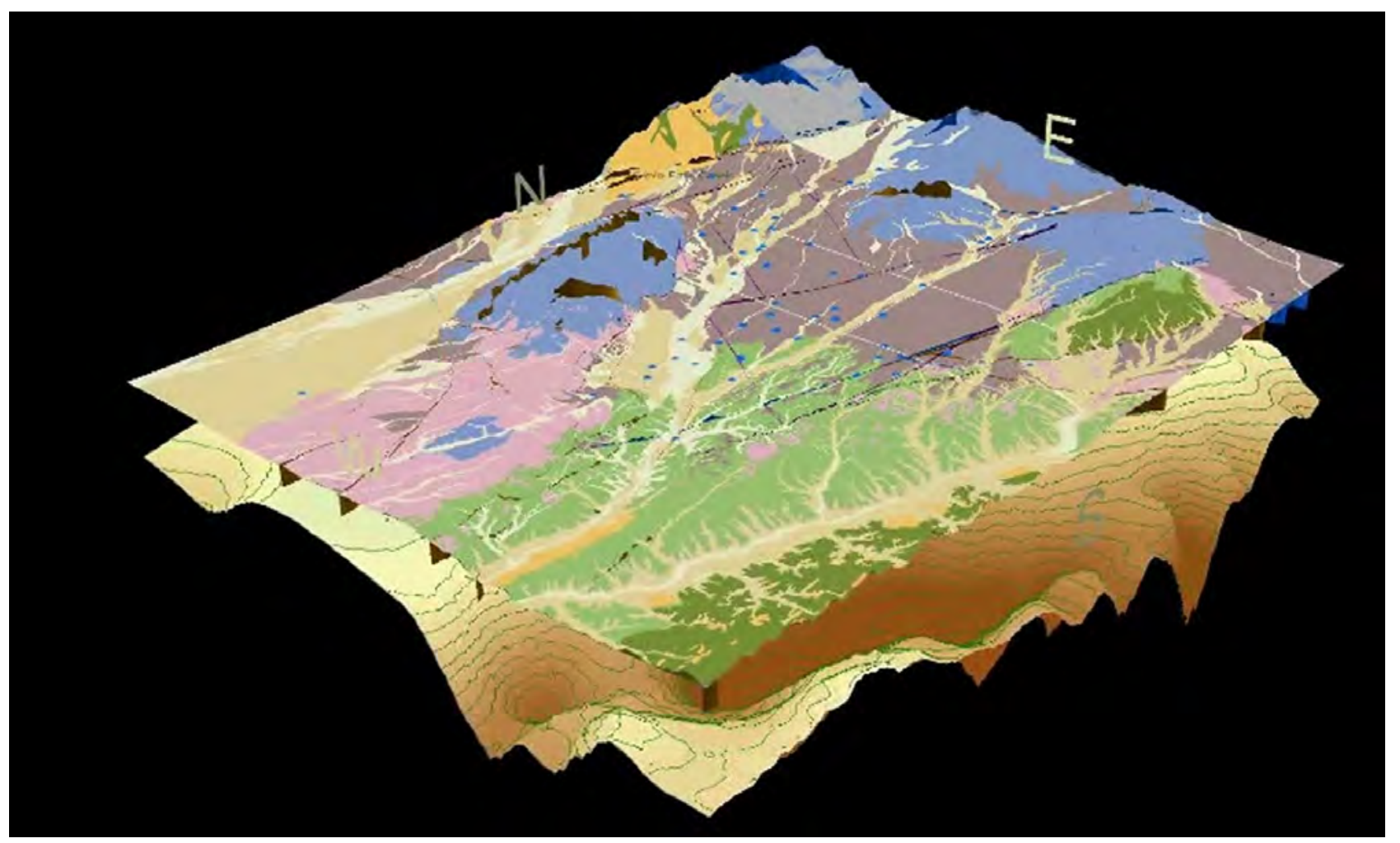

\section{EXPLANATION}

Click on image to play video

Geology-Grouped by major geologic period (Dibblee and Minch, 2003, 2008 and Morton and Miller, 2006). Surficial deposits (Holocene to Pleistocene)

\begin{tabular}{|c|}
\hline Ols \\
\hline \hline Ovy \\
\hline \hline Oya \\
\hline \hline Ooa \\
\hline \hline Ovo \\
\hline
\end{tabular}
Younger sedimentary deposits (Pleistocene) Osu Younger sedimentary deposits Older sedimentary deposits (Pleistocene to Miocene) Very young alluvium Young alluvium

QTSO Older sedimentary deposits (including San Timoteo and Mill Creek formation)

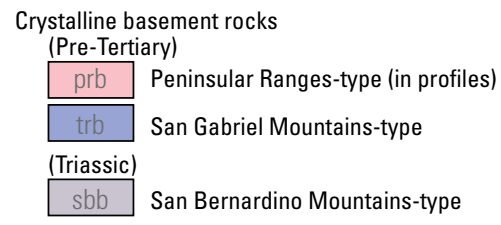

Crystalline basement rocks (Pre-Tertiary)

\begin{tabular}{|c|c|}
\hline prb & Peninsular Ranges-type (in profiles \\
\hline trb & San Gabriel Mountains-type \\
\hline (Triassic) & \\
\hline$s b b$ & San Bernardino Mountains-type \\
\hline
\end{tabular}

Subbasin boundary-Faults and barriers (Morton and Miller, 2006). Text in same color is subbasin name.

Subbasin boundary-Faults and barriers (Morton and Miller, 2006). Text in same color is subbasin name.
Fault-Solid where accurately located; dashed where approximately located; dotted where concealed (Morton and Miller, 2006).

Fault-Solid where accurately located; dashed where approximately located; dotted where concealed (Matti and others, 2003).

Fault-Solid where accurately located; dashed where approximately located; dotted where concealed (California Division of Mines and Geology, 2000).

Figure 8. Video animation showing land surface, geology, faults, wells, and basement rocks in the Yucaipa area, California. 


\section{References Cited}

Anderson, Megan, Matti, Jonathan, and Jachens, Robert, 2004, Structural model of the San Bernardino Basin, California, from analysis of gravity, aeromagnetic, and seismicity data: Journal of Geophysical Research, v. 109, no. B4, B04404, 24 p., http://dx.doi.org/10.1029/2003JB002544.

Briggs, I.C., 1974, Machine contouring using minimum curvature: Society of Exploration Geophysicists, v. 39, no. 1, p. 39-48, http://citeseerx.ist.psu.edu/viewdoc/download?doi $=10.1 \cdot 1.460 .1070 \& r e p=$ rep $1 \&$ type $=$ pdf.

Burnham, W.L., and Dutcher, L.C., 1960, Geology and ground-water hydrology of the Redlands-Beaumont area, California, with special reference to ground-water outflow: U.S. Geological Survey, 352 p., https://pubs.er.usgs.gov/ publication/1094.

California Department of Water Resources, 2004, Individual basin descriptions, Upper Santa Ana Valley Groundwater Basin, Yucaipa Subbasin: California Department of Water Resources Bulletin 118, accessed December 1, 2014, at http://www.water.ca.gov/pubs/groundwater/bulletin_118/ basindescriptions/8-2.07.pdf.

California Division of Mines and Geology, 2000, Modified from, Division of Mines and Geology, CD-ROM 2000-006 (2000), Digital database of faults from the Fault Activity Map of California and Adjacent Areas: Department of Conservation, Division of Mines and Geology.

Dibblee, T.W., and Minch, J.A., 2003, Geologic map of the Beaumont quadrangle, Riverside County, California: Dibblee Geological Foundation, Dibblee Foundation Map DF-114, scale 1:24,000.

Dibblee, T.W., and Minch, J.A., 2008, Geologic map of the San Gorgonio Mountain \& Morongo Valley 15 minute quadrangles, San Bernardino \& Riverside Counties, California: Dibblee Geological Foundation, Dibblee Foundation Map DF-381, scale 1:62,500.

Frick, Childs, 1921, Extinct vertebrate fauna of the badlands of Bautista Creek and San Timoteo Canyon, southern California: University of California, Department of Geology, Bulletin, v. 12, no. 5, p. 277-424.

Harden, D.R., 1998, California Geology: Upper Saddle River: New Jersey, N.J., Prentice-Hall, Inc., 479 p.

International Union of Geodesy and Geophysics, 1971, Geodetic Reference System 1967: International Association of Geodesy Special Publication, no. 3, 116 p.
Jachens, R.C., and Moring, B.C., 1990, Maps of the thickness of Cenozoic deposits and the isostatic residual gravity over basement for Nevada: U.S. Geological Survey Open-File Report 90-404, 15 p., https://pubs.er.usgs.gov/publication/ ofr90404.

Langenheim, V.E., Jachens, R.C., Matti, J.C., Hauksson, E., Morton, D.M., and Christensen, A., 2005, Geophysical evidence for wedging in the San Gorgonio Pass structural knot, southern San Andreas fault zone, southern California: Geological Society of America Bulletin, v. 117, no. 11, p. 1554-1572, http://dx.doi.org/10.1130/B25760.1.

Langenheim, V.E., Lee, T.C., Biehler, Shawn, Jachens, R.C., and Morton, D.M., 2006, Isostatic gravity map with geology of the Santa Ana 30' by 60' quadrangle, southern California: U.S. Geological Survey Scientific Investigations Map 2951, 25 p., scale 1:100,000, https://pubs.er.usgs.gov/publication/ $\operatorname{sim} 2951$.

Matti, J.C., and Morton, D.M., 1993, Paleogeographic evolution of the San Andreas Fault in southern California: A reconstruction based on a new cross-fault correlation, in Powell, R.E., Weldon, R.J., II, Matti, Jonathan, eds., The San Andres Fault system: displacement, palinspastic, reconstruction, and geologic evolution: Memoir-Geologic Society of America, v. 178, p. 107-160, http://dx.doi.org/10.1130/ MEM178-p107.

Matti, J.C., Morton, D.M., and Cox, B.F., 1992, The San Andreas Fault system in the vicinity of the central Transverse Ranges province, southern California: U.S. Geological Survey Open-File Report 92-354, 49 p., https://pubs. er.usgs.gov/publication/ofr92354.

Matti, J.C., Morton, D.M., Cox, B.F., Carson, S.E., Yetter, T.J., Cosette, P.M., Wright, M.C., Kennedy, S.A., Dawson, M.L., and Hauser, R.M., 2003, Geologic map and digital database of the Yucaipa 7.5' quadrangle, San Bernardino and Riverside Counties, California: U.S. Geological Survey OpenFile Report 2003-301, https://pubs.er.usgs.gov/publication/ ofr03301.

Matti, J.C., Morton, D.M., and Langenheim, V.E., 2015, Geologic and geophysical maps of the El Casco 7.5' quadrangle, Riverside County, southern California, with accompanying geologic-map database: U.S. Geological Survey Open-File Report 2010-1274, http://dx.doi.org/10.3133/ofr20101274.

Moreland, J.A., 1970, Artificial recharge, Yucaipa, California: U.S. Geological Survey Open-File Report 70-232, 88 p., https://pubs.er.usgs.gov/publication/ofr70232.

Morelli, C., 1974, The international gravity standardization net 1971 (IGSN71): International Association of Geodesy Special Publication no. 4, 194 p. 
Morton, D.M., and Miller, F.K., 2006, Geologic map of the San Bernardino and Santa Ana 30' x 60' quadrangles, California: U.S. Geological Survey Open-File Report 20061217, https://pubs.er.usgs.gov/publication/ofr20061217.

Morton, R.A., Leach, M.P., Paine, J.G., and Cardoza, M.A., 1993, Monitoring beach changes using GPS surveying techniques: Journal of Coastal Research, v. 9, no. 3, p. 702-720, http://www.jstor.org/stable/4298124.

Plouff, Donald, 1977, Preliminary documentation for a FORTRAN program to compute gravity terrain corrections based on topography digitized on a geographic grid: U.S. Geological Survey Open-File Report 77-535, 45 p., https:// pubs.er.usgs.gov/publication/ofr77535.

Rewis, D.L., Christensen, A.H., Matti, Jonathan, Hevesi, J.A., Nishikawa, Tracy, and Martin, Peter, 2006, Geology, ground-water hydrology, geochemistry, and ground-water simulation of the Beaumont and Banning storage units, San Gorgonio Pass area, Riverside County, California: U.S. Geological Survey Scientific investigations Report 2006-5026, 191 p., https://pubs.er.usgs.gov/publication/ $\operatorname{sir} 20065026$.

Roberts, C.W., and Jachens, R.C. 1986, High-precision gravity stations for monitoring vertical crustal motion in southern California: U.S. Geological Survey Open-File Report 86-44, 76 p., https://pubs.er.usgs.gov/publication/ofr8644.

Snyder, D.B., Roberts, C.W., Saltus, R.W., and Sikora, R.F., 1982, A magnetic tape containing the principal facts of 64,026 gravity stations in the state of California: available from U.S. Department of Commerce, National Technical Information Service, document PB 82-168287, 34 p.

Telford, W.M., Geldart, L.O., Sheriff, R.E., and Keyes, D.A., 1990, Applied Geophysics (Second Edition): New York, N.Y., Cambridge University Press, 770 p. 

Prepared by the Sacramento Publishing Service Center.

For more information concerning this report, contact:

Director

U.S. Geological Survey

California Water Science Center

6000 J Street, Placer Hall

Sacramento, CA 95819

dc_ca@usgs.gov

or visit our Web site at:

http://ca.water.usgs.gov 
罵

홓

$\stackrel{\bar{z}}{2}$

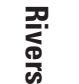

